
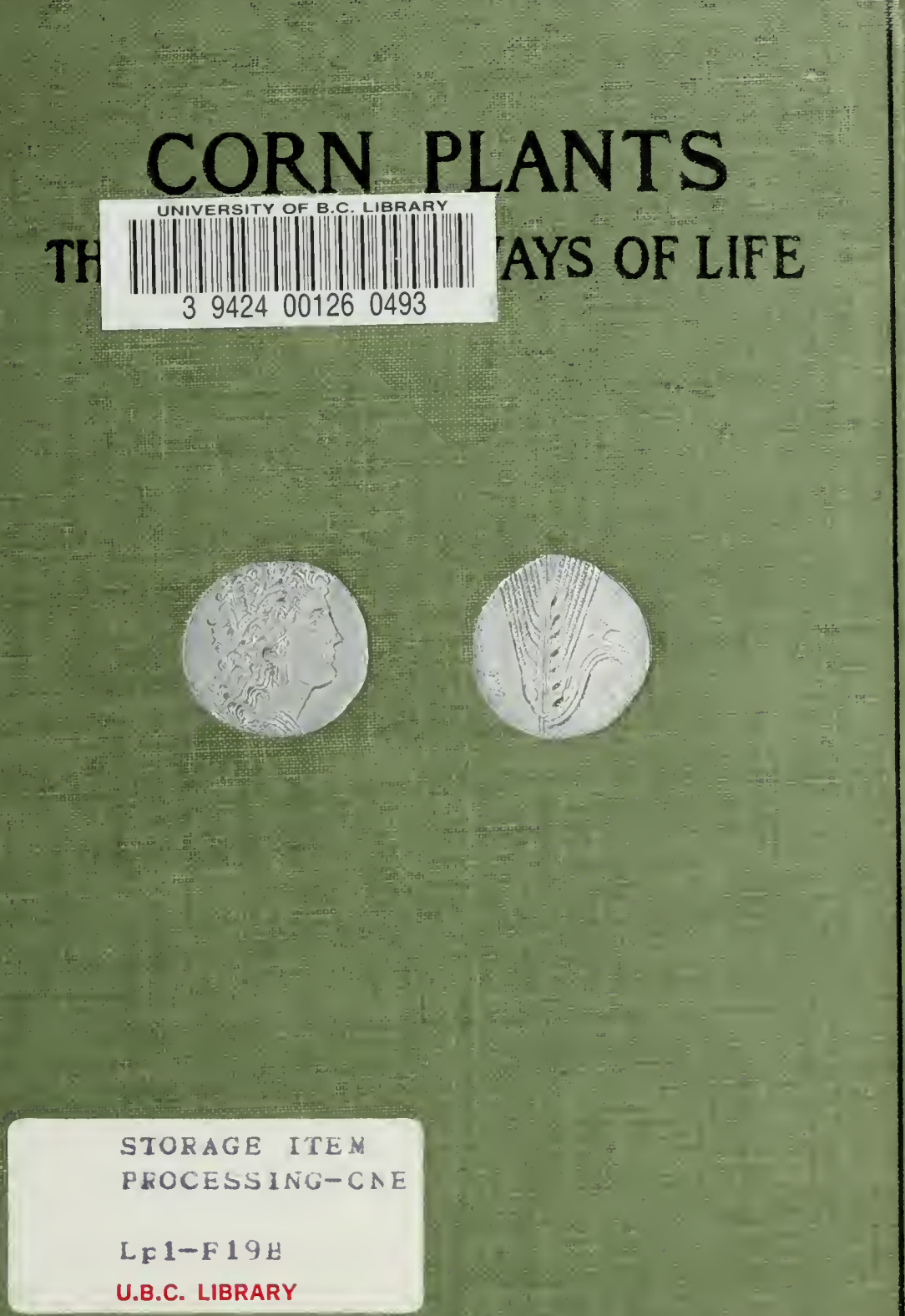

FREDERICK LEROY SARGENT 
Digitized by the Internet Archive in 2010 with funding from University of British Columbia Library 



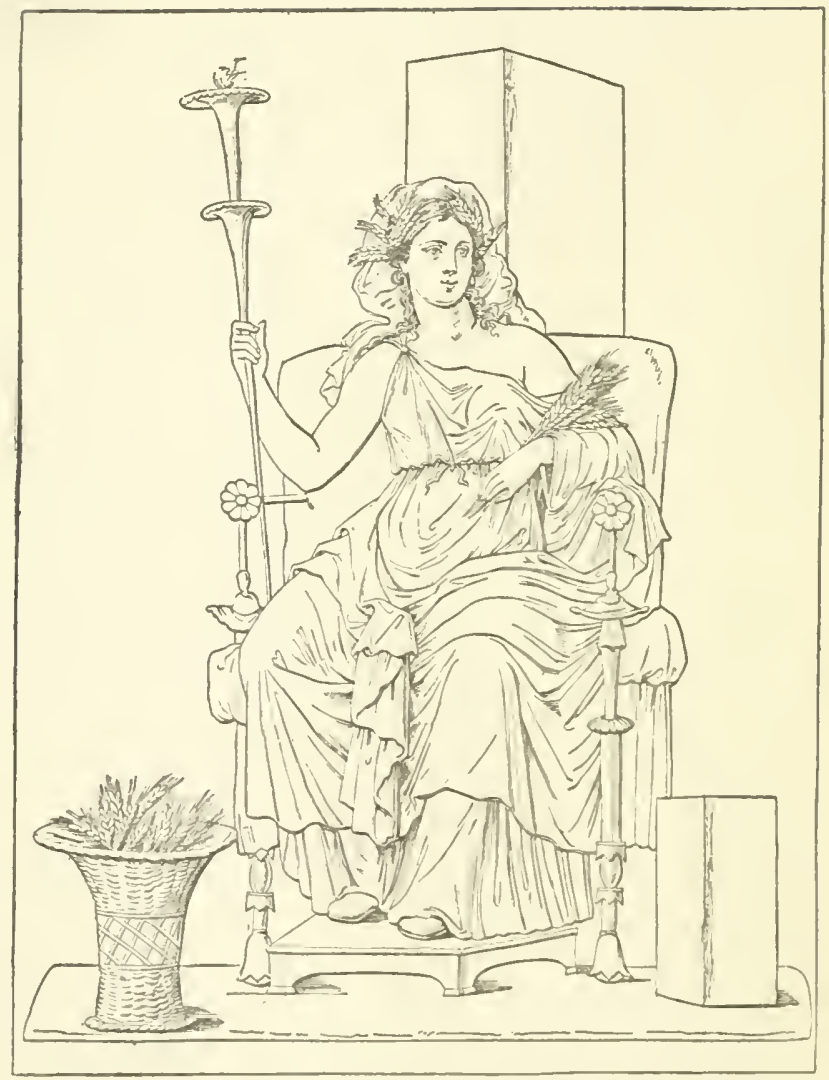

Fig. 1. Ceres, the Roman godless of grains. Wall-painting from Pompeii. 


\title{
CORN PLANTS
}

\section{THEIR USES AND WAYS OF LIFE}

BY

\author{
FREDERICK LEROY SARGENT \\ Formerly Instructor in Botany in the Lniversity of Wisconsin, and \\ Teacher in the Summer School of Botany of \\ Harvard University
}

WITH NUMEROUS

ILLUSTRATIONS
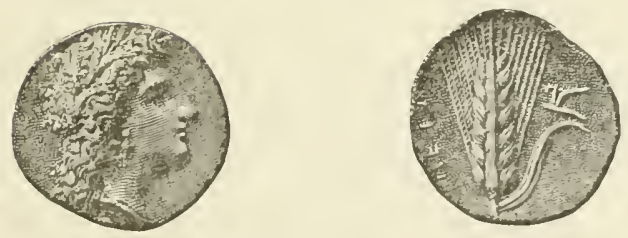

BOSTON AND NEW TORK

HOUGHION, MIFFLIN AND COMPANY

che Limersiuc pressi, Cambrioge 
COPTRIGHT, 1999

BY FREDERICK LEROY SARGEN

ALL RIGIITS RESERVED 


\section{PREFACE.}

This little volume aims to present attractively to young people trustworthy information regarding a few of the most important plants in the world. It is believed that the book will be of value also to older readers who seek an elementary knowledge of the subject, and do not object to being addressed on such matters in simple language freed from unnecessary technicalities. Not that the unwise attempt has been made to avoid all technical expressions; they have been introduced, however, always with a sufficient indication of their meaning, and none are used which all readers are not likely to welcome as saving more trouble than they make.

Although intended for use in schools, this volume is not offered as a text-book, but rather as affording profitable reading supplementary to text-books, or as giving material for teachers' talks.

The main purpose is to enliven the study of plants by showing some of their most intimate relations with our daily lives. This purpose involves the easting of helpful side-lights upon a wide range of human concerns. In these pages not only are corn plants viewed sympathetieally as living things, but the story is told of how man has been helped by them in different parts of the world, and at different periods of his 
advance from savagery. Studied in this way these familiar natural objects come to have an important edueational value in helping the student to feel those vital connections between his various studies whieh should serve to knit them firmly together in his mind. In a word, the attempt has been made to show how the peeuliarities of half a dozen supremely useful plants have affeeted the welfare of humanity, and have in turn been affected by human influenee.

Only such features of these plants have been dealt with as may be readily olserved with speeimen in hand. Aided by the illustrations it should be possible for any one to recognize in the living or the dried plant all the parts referred to, and to repeat the simple experiments suggested. Every competent teacher must realize that no pietures or deseriptions, however accurate, ean well take the place of good specimens of the objects portrayed. The best service which this little book ean render is to enhance the keen enjoyment which comes from careful and thoughtful examination of eorn plants. If the reader desires to know these plants as they are, he must see them, liandle them, and wateh them at different periods of their life.

A large share of the figures were drawn by the author direetly from nature. The others have been copied from well-known sourees which are duly indieated. 'To the hotanists of the Harvard Herbarium grateful acknowledgments are due for the use of books and speeimens. To the schoolteachers whose 
kindly criticisms have given the author much help and encouragement in his effort to meet an educational need, he would here tender his sincere thanks; and finally, he would also express his warmest gratitude to the other friends who have aided him most practically in the details of preparation.

CaMbridge, Mareh, 1899.

The silver coin reproduced on the cover and title-page is of the ancient Greek colony of Metapontum in Southern Italy, and dates from $330-314$ в. C. On the obverse appears the head of Persephone, the corn maiden, or of her mother, Demeter, the goddess of agriculture. The hair is bound with corn. On the reverse of the coin are an ear of barley and a plough, symbolizing the great fertility of the territory of Metapontum. 



\section{CONTENTS.}

I. IVhat Corn Plants are

II. The Inportance of Corn Plants to Mankind. 3

The Story of Ceres and Proserpine . . . . 3

The Roman Cereal Festivals . . . . . . . 6

Other Corn Rites and their Meaning . . . 7

III. Corn Plants in the Field . . . . . . 11

How they manage against Wind, Weight, and Wet ........... 11

Defenses against Drought . . . . . . 26

Food-making and Growth . . . . . . . 30

IV. How CORN Plants provide for their OfFSPRING . . . . . . . . . . . . 31

Seed-making . . . . . . . . . . . 34

The Floral Parts . . . . . . . . . . . 35

The Beginning of the Seed . . . . . . . 42

Ripening and Proteetion of the Fruit . . . . 48

Scattering and Planting of Seeds . . . . . . 53

The Infant Plant and its Food . . . . . . . 62

V. The Advantages of Cereals as Food Plants . 68

Yield . . . . . . . . . . . 69

Separation . . . . . . . . . . 72

Bulk . . . . . . . . . . . . 73

Keeping . . . . . . . . . . . . . 74

Summary . . . . . . . . . . . . . . 75

VI. Wineat, the Kisg of Cereals . . . . . 75

VII. Oats, the Grain of Hardiness . . . . . . 80

Vili. Rye, the Grain of Poverty . . . . . . . 83

IX. Barley, the Brewer's Grain. . . . . . 85

X. Rice, the Cors of the East . . . . . . . 89

XI. Maize, the Corn of tile IVest . . . . . . 91

XII. A General View of Corn Plants . . . . 102 



\section{LIST OF ILLUSTRATIONS.}

FIG.

PAGE

1. Ceres . . . . . . . . . . Frontispiece

2. Assurnazirpal . . . . . . . . . . . . . 9

3. Maize plant . . . . . . . . . . . . . . 13

4. Spikelet from the tassel of maize . . . . . . . 13

5. Experiment with paper tube . . . . . . . 15

6. Maize, leaf at rest . . . . . . . . . 23

7. The same, in the wind . . . . . . . . . 23

8. A young ear, a spikelet, and the upper part of a stigma of maize. . . . . . . . . . . 27

9. A ripe kernel of maize . . . . . . . . . . . 33

10. Maize kernels sprouting . . . . . . . . . . 33

11. Coyote corn . . . . . . . . . . . . . . . 37

12. Oat plant showing tillers . . . . . . . . . 45

13. Oat plant recovered from effects of storm . . . 50

14. Sheath ring of oat . . . . . . . . . . . . 51

15. Rain guard of oat . . . . . . . . . . 54

16. Inflorescence of oat . . . . . . . . . 58

17. Diagram of oat spikelet . . . . . . . . 59

18. Spikelet of enltivated oat in fruit . . . . . . . 65

19. Spikelet of wild oat in fruit . . . . . . . . . 6 J

20. Rice, part of a plant, a spikelet and a ligule . . . 71

21. Rice, infloreseence, spikelet, flower, and kernel . . . 77

22. Rice, a bearded spikelet and part of the awn . . . 77

23. Inflorescence of rye . . . . . . . . . . 81

24. Spikelet, bracts, and kernel of rye . . . . . . . 81

2.5. Inflorescence of common bearded wheat . . . . . 87

26. Inflorescence of club wheat . . . . . . . . . 87

27. Spikelet, rachis, bracts, pistil, and kernel of wheat . 93

28. Common barley, inflorescence. . . . . . . . . 97

29. Two-rowed barley, inflorescenee . . . . . . . . 97

30. Six-rowed barley, spikelets, flower, and kernel . . . 99

31. Wild oat-grass, flowering spikelets showing arrangements for pollination . . . . . . . . . . 101

32. Map, showing probable native homes of various corn piants . . . . . . . . . . . 103 



\section{CORN PLANTS.}

\section{What Corn Plants are.}

IT is somewhat curious how differently the word "corn" is understood by different peoples. In the United States we generally mean by it simply maize or Indian corn ; but the Scotch use it as meaning oats, and to most Englishmen an "ear of corn" suggests nothing but a head of wheat, while throughout the northern part of the European continent a "cornfield "is understood almost always as a field of rye.

If we turn to our Authorized Version of the Bible we find the word "corn" used in several interesting ways. It is said that Ruth coming to Bethlehem "in the beginning of the barley harvest" asked "to go into the field and glean ears of corn " (Ruth i. 22 and ii. 2). But it was "in the time of the wheat harvest" that Samson burned "the standing corn of the Philistines" by tying firebrands to the foxes' tails (Judges xv. 1,5). The humane statute of Moses "Thou shalt not muzzle the ox when he treadeth out the corn" (Denteronomy xxv. 4) undoubtedly applies to all the grain plants harvested by the Israelites. Finally, in the words of Jesus, " except a corn of wheat fall into the ground and die, it abileth alone" (John xii. 24), the meaning of corn is plainly liernel.

How did "corn" come to liave these different meanings? The dietionary tells us that the word first 
meant simply a hard, edible seed, grain, or kernel, ${ }^{1}$ and was applied especially to such kinds as were of most importance for fool. From this it would be but a short step to speak of the plants which bore snch kernels, as "corn plants" or "corn" in general. Then whicherer of these plants was most familiar to a people naturally came to be known as "the corn" of that region, or simply as "corn," while those corn plants which were in less common use were distinguished by their separate names. Thus we account for the different ways in which "corn" has been understood by different people at different times. In this book we shall use the word as a general name to include wheat, barley, rye, oats, rice, and maize - the six plants which produce the principal breadstuffs of the world, and the most valuable of all vegetable foods."

I An example of this use is found in the word "barleyeorn," which means either a kernel of barley or a measure of length, three barleyeorns being equal to one ineh.

2 The general name "corn" is applied also to several other plants which resemble more or less the six above named. 'Thus, there is the Kaffir- or Guinea-corn, otherwise known as dhourra or Indian millet. This is extensively used for food in $\mathrm{A}$ friea and Sonthern Asia. Then there are the true millet, and the Italian millet, which are somewhat similar plants that have been long enltivated in the Old World. In Central Ameriea a eom-like plant ealled teosinte is highly valued for food. Quinoa, a south Amerienn plant very like our common pigweed, produees grain much used in the monntainous regions. These and also luckwheat, which is grown to a eonsiclerable extent in many countries, are sometimes inchuled among corn plants : but all of them, and others which might be mentioned, are of so much less importanee to us than are the six great eorn plants named above, that we shall not need to eonsider them further in these pages. 


\section{The Importance of Corn Plants to Man- KIND.}

Corn plants, as we know, are called also cereals or cereal grains. How they came to receive this name is a question which is of interest not only becanse the answer must lead us very far into the past, but also because it will help us to realize how important these plants have been to civilized people from the earliest times.

Like so many of our words this name is of Latin origin, and was used in nearly its present form by the ancient Romans over two thousand years ago. The people of those days, as we know, had many myths. These often meant a great cleal to them, for it was only through such stories of gods and heroes that they felt able to account for the wonders of nature. Of all these ancient myths one of the most beautiful and significant was the following, which will aid us in understanding the origin of the name "cereal."

\section{The Story of Ceres and Proserpine.}

Ceres was the goddess of agriculture and especially watched over the growth of grains. (See Fig. 1.) Proserpine, her only danghter, was a girl of wonderful loveliness and the joy of her mother's heart. When the world was new they dwelt together upon the earth. The maiclen loved flowers dearly and was never happier than when playing among them in the fielkls. One day she strayed off by herself to gather some rare blossoms which grew in a eertain valley. There Pluto, the god of the underworld, chanced to see her, and so charmed was he by her exquisite beauty that he determined at onee to earry her off, 
that she might always live with him and brighten the gloom of his realm below. As he eaught up the frightened girl into his golden chariot, her flowers fell to the ground. So also did the girdle which she had worn. When night eame and Proserpine did not return, Ceres was filled with fear lest some harm had befallen her daughter. With torch in hand she searched far and wide. Dawn came and found the poor mother distraeted with grief and still wandering with the lighted torch. No one whom she met could tell her where Proserpine had gone, though all were moved with pity. Day after day and night after night she searehed, passing through many lands, till at last she came to a place in Greece called Eleusis. Here, utterly discouraged, she sat down to weep. Toward nightfall a poor man and his wife found the goddess, thus bowed with grief, and, thinking her to be a mortal, tried to eomfort her. They offered her the hospitality of their home. They, too, were full of sorrow, for their only son, Triptolemus, was siek unto death. Tonched by the tender kindness of these good people, Ceres went with them, and to their exceeding joy healed Triptolemus. Then revealing her true nature she promised some day to teach the lad what would make him honored by all mankind. She then eontinued her anxious seareh, yet with a lighter heart, for the hope had come again that she might soon find some trace of her daughter. It was not long before she eame upon a bumch of withered flowers and the girdle which Proserpine had let fall from the ehariot. Near by was a huge eraek in the ground. Now Ceres felt sure that the earth had opened to swallow her child. Full of anger at the earth's ingratitule the goddess eursed the land, and brought drought and 
famine. Though every creature suffered, still even those who knew well what had happened dared not tell Ceres, for fear of Pluto's wrath. At last the nymph of a certain fountain which flowed from the underworld was so moved by all the misery which had come upon the earth, that she could hold the secret no longer. So, when Ceres came one day to the fountain, the nymph cried out to her, "O Goddess, blame not the land for what has befallen! I have seen thy daughter in the realus below. Pluto has made her his queen." On hearing this Ceres hastened to the throne of Jupiter, chief of the gods, and implored hin to give conımand for Proserpine's release. This he agreed to do, provided the maiclen had eaten no food while in the lower world : for so willed the Fates, whom even the gods obey. But alas! it was found that she had tasted some of the pulp of a pomegranate which the wily Pluto had given her, and in so doing had put six of the seeds into her mouth. She was dooned therefore to remain six months of every year with Pluto in the world below; but for the other half of the year she was permitted to live in the realn of sunshine with her mother, and each year Spring was to lead her forth. Pluto had been so kind to Proserpine that she had grown fond of him and did not feel at all sorry abont the seeds. Ceres was content in that her dlaughter was so far restored to her. Bestowing once more her favor on the land she caused it to bring forth abundantly. She remembered, moreover, her promise to Triptolemus and taught him the use of the plough, the sowing of seed, and the raising of grain. These things, in his turn, he taught mankind, and thus through his teachings eame the beginnings of agrieulture. 
As the reader has doubtless already diseovered, we have in this charming myth little more than a poetic story of the corn plant, which, like Proserpine, passes a season in the earth, awaiting the gentle hand of Spring to lead it into the light of day. Also we have the thought that the beginnings of agrienlture came with man's first knowledge of the growth of grain.

\section{The Roman Cereal Festivals.}

That sueh was the real meaning of the myth to the ancient Romans is shown by the way in which they celebrated their great agricultural festivals. These were held each year at springtime and harvest. From the twelfth to the nineteenth of April eame a series of important ceremonies in memory of the return of Proserpine. Throughont the country the people marched in procession around their fields, imploring the favor of Ceres upon the growing grain. In the city the worshipers, all dressed in white, went to the temple of Ceres, bringing incense and honey, and eakes of wheat and barley as offerings to the goddess. On the last day of the festival elaborate games were held in her honor. The seeond festival coming in August was a feast of thanksgiving. At this the firstfruits of the grain harvest were bronght as an offering to Ceres. The ceremony was performed by women alone, dressed as before in pure white. So sacred was this office consiclered that a fast of nine days was required as a preparation.

The gifts to Ceres, offered at these festivals, were ealled by the Romans cerealia munera (Ceres' gifts), or simply cerealia. We ean now answer our question as to how corn plants came to be known as "eereals." Since by far the most important of the gifts to Ceres 
were from wheat and barley, it was very natural that these plants should come to have the name cerealia or cereals applied especially to them; and when other similar grains came into use, it was equally natural that they should be included under the same general name. Thus it was that the word eame finally to have the wide sense in which we use it to-day.

\section{Other Corn Rites and their Meaning.}

How eame the Romans to have this story of Ceres and Proserpine? The fact is that they borrowed it from their neighbors, the Greeks. Long before the Romans began to hold their cereal festivals, the Greeks celebrated with even greater magnificence what were known as the "Eleusinian Mysteries." These were so called because the chief ceremonies took place at Elensis, the home of Triptolemus, where, as the Greeks believed, this great benefactor of mankind had first established the worship of the goddess of grains. The celebration of these "Mysteries," which took place early in autumn, formed the great religious event of the year. It lasted many days, and the various ceremonies were arranged to commemorate in a striking manner the doings of the leading persons in the myth of the corn maiden. But most significant of all were the coneluding rites, in which the worshipers were permitted to handle and taste the sacred symbols of the goddess, and finally amid profound silence beheld a living corn plant cut down by the priest.

In the Hebrew Seriptures we read of the Israelites, at the yearly festival of the Passover, preparing, at Moses' command, unleavened bread in memory of their flight from Egypt; and also as part of the same celebration, bringing the first sheaf of the harvest as 
an offering to Jehovah. After the harvest was gathered came the festival of Pentecost or Harvest Feast, when, amid great rejoicings and thanksgivings, loaves of leavened bread were brought before the Lord. "The whole ceremony," says a learned writer, "was the completion of that dedication of the harvest to God, the giver, . . . which was begun by the offering of the wave-sheaf at the Passover." 1

Among the Assyrians and Babylonians who were akin to the Hebrews, and dwelt in the fertile valley of the Tigris and Euphrates, we find evidences of a similar appreciation of the value of corn plants. One of their ancient monuments recently discovered shows a great ling in priestly robes offering for a sacrifice an ear of wheat. (Fig. 2.)

As wheat was valued by the peoples of Assyria and Babylonia, so has rice been held for ages in the highest estimation by the people of China. One interesting proof of this is a royal ceremony of seed-planting, believed to have been instituted by one of their emperors who reigned 2700 B. C. Every year for these many centuries the seeds of rice and of four other food plants have been sown with appropriate rites by members of the govermment. The rice is always planted by the emperor in token of its supreme importance.

We learn from accomts of early explorers in the New World that maize was similarly valued by that remarkable people, the Nahuas of ancient Mexico. This grain was extensively cultivated as the staple crop of the region, and in much the same way in which the Romans sacrificed to Ceres the firstfruits of their grain harvests, the Nahuas offered with elaborate

1 See Exodus xxix. 23, 24. 


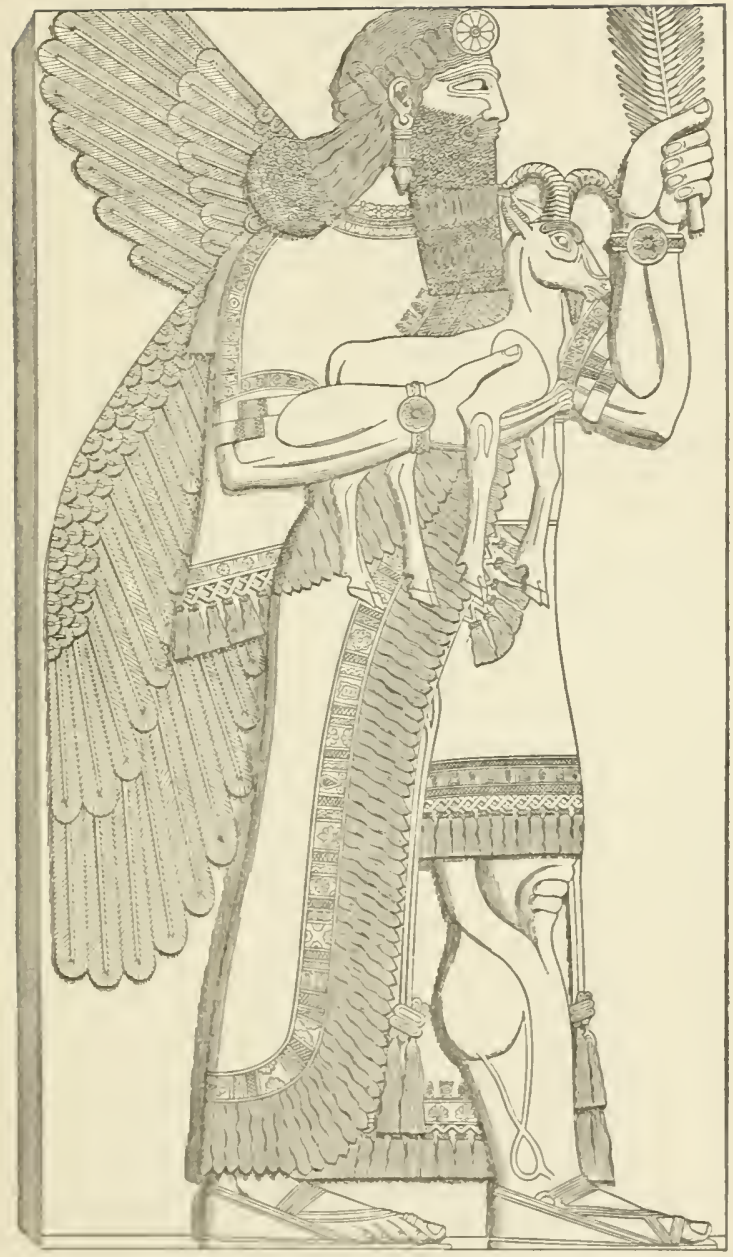

Fie. 2. Assurnazirpal, king of Assyria ( $\$ 33-8.59$ в. C.), as priest offering a kid and * head of wheat for a sacrifice. Bas-relief. (Layard.) 
ceremony the firstfruits of their cornfields to Centoatl, their goddess of maize. The ancient Peruvians almost worshiped the maize plant as a divinity. At harvest time, as they returned home singing from the fields, the people reverently carried a large bundle of maize wrapped in rich garments. This they called by the name of their harvest deity, Perua. For three nights they continued the worship of Perua, imploring protection for the maize they had gathered.

When our forefathers cane to this comtry they found the "Indian corn," as will be remembered, largely cultivated by the aborigines of North America. In fact it was to this fortunate circumstance that many of the colonists owed their lives; and we may well believe that if it had not been for the corn of the Indians, the brave attempts to establish colonies in the colder parts of the New Morld might have failed for lack of food. Hence in the celebration of our Thanksgiving Day, since this festival was founded by those who were thus sustained, it has been deemed particularly appropriate that especial prominence should be given to Indian corn among the grains which are used in church decoration and otherwise on that occasion.

From what has been said and from what is to follow, it will be seen that throughout the world there has been from earliest times the closest connection between the growing of grains and the progress of mankind - that, in a word, cereals and civilization liave ever gone hand in hand. Moreover, it will appear that as nations have alvanced in culturc and importance, their dependence "1pon corn plants has been not less but greater. In this we may see the reason why among all peoples these plants which have yielded 
to them their daily bread have ever stood as a symbol and supreme example of the best gifts of the Giver of Life.

\section{Corn Plants in the Field.}

Why it is that corn plants play so important a part in our daily lives, and why certain of them are more highly valued than others, are questions which must be answered by referring to peeuliarities of the plants themselves. We shall be helped, therefore, in trying to understand the deep eonnection between our lives and theirs, if we consider first the way in which they live.

How they Manage against Wind, Weight, and Wet.

It may be said in general of all these plants that they are never so much at home as when growing in broad, wind-swept fields. A special fitness for such life in the open is shown in every part of a corn plant and in its whole behavior. We may well credit those who tell us that in order to realize fully what corn plauts are like when at their best, one should see them growing in the vast fields of our great Northwestern States.

Not long ago I heard of a little girl who had come East from a ITestern wheat farm. She had never seen the oeean, and when taken to get her first view of it she did not seem to be so much impressed as her friends expeeted she would be. After a while they asked her if she did n't like it. "Oh yes," she replied, "I like it very well beciuse it has waves, but I like the waving wheat at home a great deal better." Those of us who have seen the oeean only may wouler at such a comparison, but it will not surprise us when 
we stop to think that not even the Atlantic can give a greater impression of immense extent than a grain field stretching out on every side as far as the eye can reach.

The very eharacteristic and beantiful ware effect, which every one has noticed in a field of grain as the leaves or ripening heals bow before the wind, is made possible by a remarkable arrangement of elastic material in the framework of the plant. If we examine one of the long, slender leares, we find it to be strengthened by numerous spingy threads extending from base to tip. They form a sort of slieleton for the leaf. In the larger leaves of corn plants, espeeially those of maize, we find, besides the many slender threads which run side by side throughout the length of the leaf, a bundle of threals of extra thickness and strength, ruming like a backbone through the middle of the blade. It is owing to these threads that the blacle of a corn plant when at rest naturally talies a broal, graceful eurve, like that shown in Figme 3. Yet the springs are so delicately elastic that they yield at the slightest breatl of air, while the leares are so formed as to allow a stronger wind to pass with only the least possible pull upon the stalk.

In the stalk we have the same sort of springy material formed into similar theads, lunt, instead of being in a flat row like those of the leaf-hlade, they are arranged in the form of a tule. The tulular form gives mueh erroater stiffuess, and that is what the stem especially neods, sinee it las not only its own weight to support hut also that of the leaves and, in comse of time, the fruit. ${ }^{1}$

1 We mean hy frut the seeds and whatever adjoining parts ripen in connection with them. 


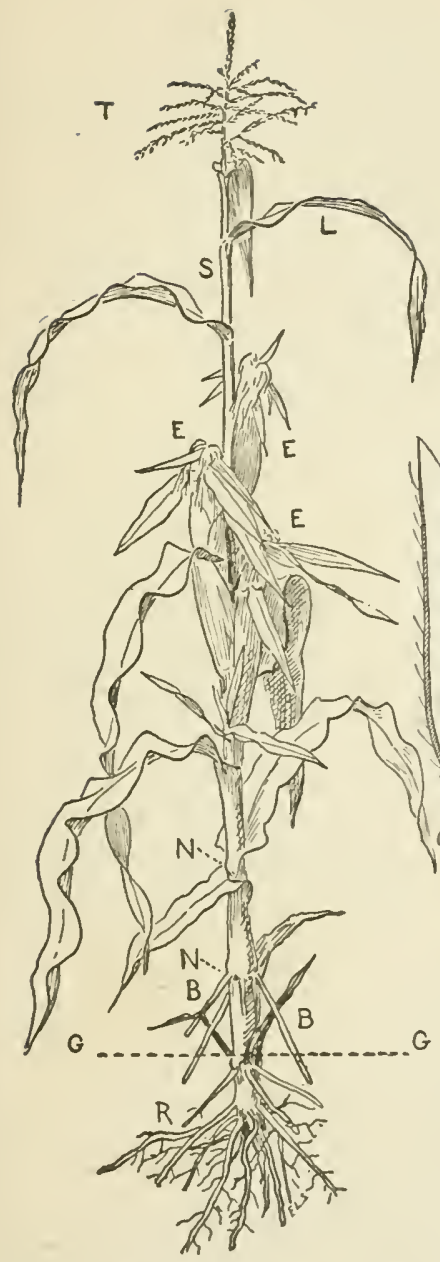
Fia. 3. Maize plant. T, tassel; $S$, stalk ; one cut to show the pollen. Enlarged. L, leaf ; $\mathbf{E}, \mathbf{E}, \mathrm{F}$, ears ; N, N, wotles ; $\mathrm{B}, \mathrm{B}$, (Origiual.) brace roots; $R$, earth roots; $G, G$, surface of ground. (Original.) 
The great advantage derived from the tubular arrangement is well shown by the following simple experiment. Take a piece of writing paper, say eight inches long by three wide. Observe that when flat it has not stiffness enough to sustain even its own weight in an upright position. Now roll it lengthwise into a tube about three quarters of an inch in diameter, and to prevent its unrolling slicle on to the tube three squares of paper having a hole of the same diameter as the tube cut from the centre. Place the tube upright on the table and arrange books as shown in the diagram (Fig. 5) at P, B and G, so that the middle of one end of the book $B$ will rest squarely on the tube. If now on this support additional books (W) be placed carefully, one at a time, it will be found that the tube will hold up a weight likely to astonish any one who has never tested the strength of such a seemingly feeble column.

Moreover, builders have discovered that in making a column for support the tubular form gives far greater strength than if the same amount of material were made into a solid cylinder. Hence the use of tubes as far as possible in bicycle frames, which require the utmost strength attainable with a small weight of material. There is only this drawback, that when the tube is very long in comparison with its width there eomes the danger of collapse or flattening and falling together of the sides. In the grain stalk this is avoided by means of solid joints ${ }^{1}$ called nodes,

1 As the word "joint" is liable to be misunderstood, since it may mean either the place of a partition or a portion extending from one partition to another, we shall avoid eoufusion by using the botanieal terms node (from the Latin nodus meaning a knot) and internode (Latin inter, between). 
which act as cross partitions dividing the whole stem into a series of tubes (the internodes) each of safe length. (Figs. 3, 12, 13, and 14 II.)

It should be noticed, also, that the need for stiffness is not the same in all parts of the stem, but increases towards the base; for, plainly, the weight to be upheld

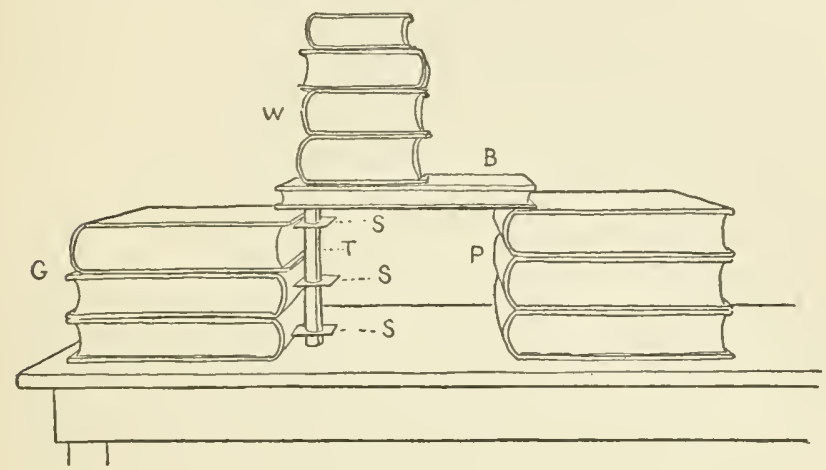

Fig. 5. Experiment with paper tube. T, paper tube; S, S, S, pieces of paper slipped over the tube to prevent unrolling; $\mathrm{P}$, pile of books as high as tube; $\mathrm{B}$, book, of which one end rests on $\mathrm{P}$, while the other is supported by the tube; $\mathrm{W}$, books added as weight; $G$, pile of books slightly lower than $P$, coming under $B$, to guard against fall of $W$. (Original.)

and the bending strain caused by wind become greater and greater in the lower parts. To provide this extra stiffness the distances between the nodes are less and less as the base is approached, while at the same time there is in the internodes some thickening of the wall.

As we pass upwards from the base of the stem not only does the need for stiffness become less but there is a steadily increasing need for as much springiness as possible. This is necessary in order that the upper parts may yickd readily before the wind, and allow it to pass with least resistance, and lience with least 
strain upon the lower portions. We know that a slender rod is the best form to secure flexibility in every direction, just as a tube is the form of greatest stiffness for a given amount of material. As miglit be expected, therefore, we find the upper portion of grain stems increasingly slender and the eavity of each internode becoming much less in proportion to the wall. That is, the internodes are more and more rodlike, until finally the uppermost are nearly or quite solid. We see this particularly well shown in the upper branchlets of the oat stalk, where the springy material is made into wirelike supports well-nigh as delicate and elastic as the steel hairspring of a watch.

An apparent exception to the general rule that corn plants build their stems on the tubular principle is found in the stalk of Indian corn. Here, instead of a cavity, as in the straw of the other cereals, there is a core of pith through which rum lengthwise a few slender threads. But we have only to remove a thin ring of the outer firm material of a maize stalk to find that the inner part, although forming the main bulk of the stem, is in reality very weak. Indeed, its value as an element of strength may be compared to a filling of sponge put into our paper tube. Hence we must conclude that whatever may be the use of this core of pith, the strength of a maize stalk is gained chiefly by its tubes of firm material, quite as truly as in the case of the other cereals.

These tubes of the maize stalk, it should also be said, are not always entirely eylindrieal (as they are in the straw of other corn plants), but at several of the internodes are grooved or flattened on one sicle. Those of my readers who have ever made a "coln stalk fiddle" will remember that it was this peenliar 
flattening which rendered possible the manufacture of that rustic instrument. The part of the stalk chosen for the purpose always includes an internode which has one side flattened against an ear. Along the edges of this flattened part run woody threads of remarkable toughness, which provide the strings for the fiddle. With a sharp knife these threads are separated from the rest of the internode except at the ends where they join the nodes, and are then stretched over a "bridge" consisting of a cross slice cut from a neighboring internode. When played upon by a "bow" made from the upper and more slender part of the stalk, such a fiddle will give forth a perceptible if not always an agreeable tone.

In making this interesting toy one is led to observe certain facts which help to an understanding of the peculiar form of the maize stalk. Thus the fact that those internodes which are grooved have each an ear on the grooved side clearly indicates that this form helps to make room for the growth of the young ear. Moreover, any weakening which may result from the change of form is largely offset by the extra strength of the woody threads. It will also be noticed that usually the only internodes which are much flattened are those that come well above the base and hence are not so much subject to strain. The lower internodes, which have the greatest strain to bear, are, as we should expect, almost if not entirely cylindrical. Finally, it may be remarked that even the flattened internodes are really constructed on the tubular principle, although they are not quite so strong as if, with the same amount of material, they had been cylindrical in form.

We have seen that the tubular form of stem is the 
one which makes the strongest sort of a column that ean be constructed with a limited amount of material. But we may also view it as the form requiring least material to be used in making a column which must have a given strength. When the tubular prineiple of stem construction is viewed in this way, it becomes plain that corn plants aceomplish an important economy of their building material. This saving will in part aecount for the remarkable height which they attain during their short season of growth.

Another peculiarity of corn plants which greatly favors their rapid increase in height is the way in which new material is added at a number of separate places along the stem all at the same time. With most plants, as is well known, the stem becomes longer by the addition of new material entirely within a young and tender region at the tip. The way such a plant grows in length we may liken to the extension of a pocket telescope, when the seetions beginning with the lowest are pulled out one at a time. If there were four sections to pull out and we took, let us say, one minute in pulling out each, then it would of course require fom minutes to bring the telescope to its full length, in this way. Suppose, however, that instead of pulling out the sections one at a time, we could so manage that all of them would be extending at the same time and each as rapidly as before, then, plainly, the teleseope would reach its full length in one minute. That is to say, in the second case, we should be pulling out the telescope four times as rapilly as in the first, or, in other worls, as many times faster as the number of the seetions extending at once. With corn plants, as we shall see, the extraordinarily rapid increase in length of stem is accomplished by having 
many sections extending at once, in much the same way as in our imaginary telescope.

Let us now see what we actually find in a growing grain stem. During the period of rapid elongation an examination of one of the older internodes even will show that while the upper portion has become so firm as to be incapable of further growth, the portion below is still rather tender, and near its base it is as full of sap and vigor as the tip of an ordinary shoot in springtime. Each internode by having its own special region of growth, which remains active for a comparatively long while, is therefore able to add to its length at the same time as the growing parts of the other internodes. Moreover we must not forget that in cereals, as well as in other plants, the stem grows also at the tip. This makes the extension of the separated growth regions of the older internodes in cornlike stems just so much clear gain for the plants which have this advantage. A large share of the life of field plants is an upward striving for light and air. The weeds which grow beside our cereal grains are for the most part easily beaten in this race, for they have not learned the secret which makes corn plants supreme. It would be hard to find among self-supporting plants a more rapid grower than maize, for example, which sometimes during its few months of growth reaches a height of nearly twenty feet.

Thus far we have been eonsidering the stem as if it were the only part concerned in maintaining an upright position against the pulls of weight and wind. In any fair distribution of eredit, however, the leaves, must come in for a large share. The earliest green of the infant plant, which makes its way to the sur- 
face of the ground, is leaf, and until the appearanee of a "tassel" or "head" at the top of the elongated stalk, a leaf-blade always forms the uppermost part of the plant. At first the whole leaf is rolled into a tube. As it grows, the upper part unrolls into a long fat blade. This blade bending ontward exposes the rolled blade of a younger leaf. This younger leaf may in turn inclose a succession of still younger leaves, which will in time come out, but until they are ready to appear, each of them is infolded by the leaf next older than itself. Unlike the blade, the lower part of each leaf even when full grown does not unroll, but remains as a tubular sheath tightly wrapped about the stem. It thus reinforees the internode in the best possible way, especially toward the base where the younger growth makes support and protection most necessary.

By this admirable arrangement of tube within tube, each of the growing parts is given all the protection it needs, but no more than is good for it at any time. The youngest and tenderest leaves are the most protected. As they grow older and are better able to protect themselves, they are permitted more and more to do so, and at the same time they become of increasing importance as guards to the younger growth within. For the baby leaves, a tube forms the snuggest sort of a cradle. Noreover, the tubular form also enables the leaf to do stem's work, and this in two ways: first, in the blade, secondly, in the sheath. The blade, so long as it remains mnrolled, grows, as we have seen, witl remarkable rapidity, straight upwards in advance of the stem. The sheath, by retaining permanently its tubnlar form, continues not only to protect but also to give firm support to the lower 
end of the internode, which it infolds. In military language, it may be said that the blade forms the vangnard, while the sheath serves as the rearguard of the column.

Besides the mechanical support which a sheath provides and the protection it affords as a covering, there is yet another advantage gained by most corn plants from having the lower part of their leaves in the form of a cylindrical tube surrounding the stem. It will generally be found that the sheath, although firmly fixed at its lower end, revolves more or less freely in its mper part around the stem. This amount of play in the parts, as a trial readily shows, permits the blade to swing horizontally through nearly lialf a circle without bringing to bear on the stem more than a very slight twisting strain. The importance of this additional provision for lessening even the small resistance offered to the wind by these delicately responsive, pennon-like leaves will be apparent when we remember to what severe tests such field plants must often be subjected.

In maize there is still another provision for lessening the strain of the wind-tossed leaves on the stem. As the blade elongates, the parts toward the edge grow much more than the middle portion. Hence, the margin is thrown into the ample folds which give such a beantiful wavy effect to the leaf. (Sce Fig. 3.) At the base of the blade, on each side of the "backbone " or "miclrib," are folds of especial prominence. (F, Figs. 6 and 7.) When the wind blows, say on the left side of a blade, the folds on that sicle permit the elastic midrib to bend readily away from the wind to a considerable extent before the erlge is tant. Meanwhile, the other half of the blade, on the right of the 
midrib, is being folded into more of a ruffle; or it may be that the blade avoids the full force of the wind by a spiral twist which is made particularly easy on account of the ample edges. In any event the prominent folds at the base of the blade permit the midrib to bend at that point almost as if hinged. Thus in these largest of coln leaves, even though the sheath be immovable, a very wide swing away from the wind is made possible by simple means.

It is generally found to be true in mechanies that wherever special delicacy of action is required the danger of getting out of order is correspondingly increased. So it is with the revolving mechanism of the sheath. Since the successful operation of this depends upon the easy sliding of an outer tube upon an inner, danger arises from the possibility of rain getting in between the tubes and carrying along partieles of dust or agencies of decay. Not only would this interfere more or less with the free swing of the leaf, but the accumulation of such particles, together with the moisture, might seriously injure botl the stem and the sheath. Even in maize, where the sheath is immovable, such accumulations would be dangerous. To avoid all this is doubtless the purpose of that special outgrowth of the leaf at the junetion of blade and sheath shown in Figure 15, 1R. This outgrowth, which we may call the rain guard, is generaily pressed close to the stem, and along its line of mion with the blade there is formed a broad channel to right and left. Whatever water may flow along the blade toward the stem is by this means carried around the rain guard to the opposite side, and there falls down over the sheath to the next rain guard below. Here the stream is similarly led 


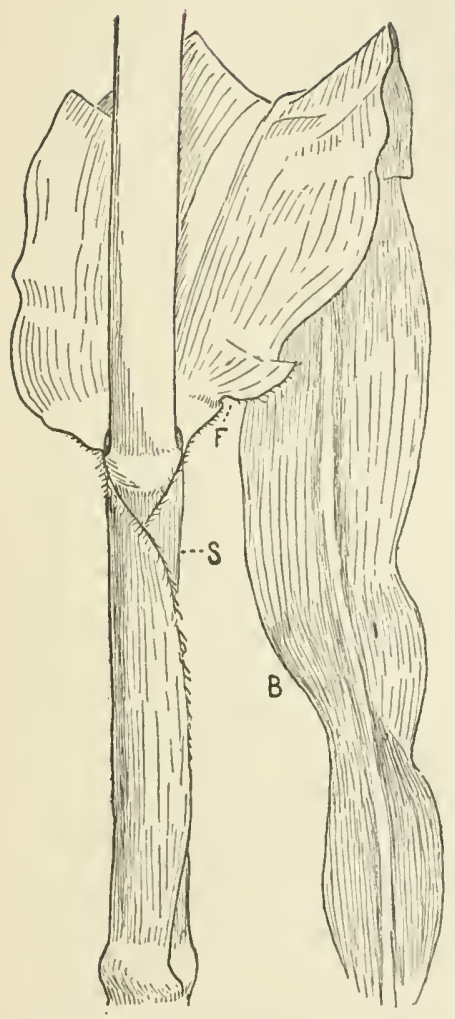

Fia. 6. Maize, leaf at rest. B, blade; S, sheath; F, a region of epecial fullness. (Original.)

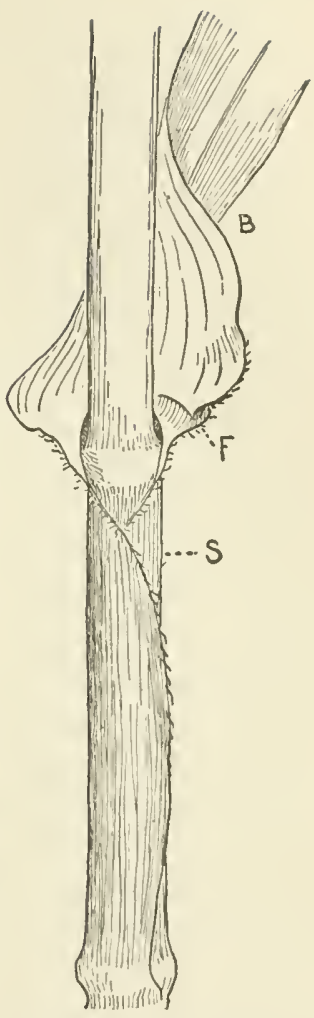

Fia. 7. The same, with the blade (B) blown to the right and thereby twisted, and a deep fold male at $F$, thus relieving the sheath (S) and the stalk of strain. (Original.) 
around the stem once more, and dommward, and so on till it reaches the roots. Thus, these several parts coöperate to lead the water away from where it wonld be harmful to where it is of greatest use. All this may be readily observed by watehing a growing grain plant during a shower, or by imitating the effect of rain by a watering-pot.

When we were eonsidering the strains coming upon an upright stem, we found that these must steadily increase towards the base, and thus beeome greater near the surface of the earth. This extra strain, as will be remembered, is met by having the lower internodes both thicker and shorter than the others. ITe have now to add the interesting fact that the forces of wind and weight are still further resisted by certain special roots which grow out from nodes near the ground. These brace roots, as they are called, extend on all sides obliquely downwards into the soil, and thus help to keep the stem upright in much the same way that shrouds support the mast of a ressel. As we should expeet, the lest examples of such roots are afforded by maize (Fig. 3), for this is by far the tallest of the corn plants, and most needs the extra support. The brace roots of maize are of especial interest also, from the fact thit they of ten become remarkably stiff, and thus serve as props as well as shroudlike stays.

Wrere it not that eorn plants have sueh effective means of resisting or avoiling the constant pushes and pulls upon every part, they could not aceomplish their remarkable wrowth in the fields. Uncler all ordinary ciremustances these brave plants manage to hold their own in a way that must win our admiration. But a moment's thought will show that howerer strong 
the lower parts may be and however widely spreading the brace roots, their strength is of little account unless the soil affords a firm anchorage. Hence, if a violent rainstorm soften the ground or perhaps wash away so much of the earth as to uncover the upper roots, then nothing can save these plants from being blown over flat upon the ground. To any one not familiar with the ways of corn plants, a field of grain overthrown seems hopelessly ruined. Yet the farmer knows better. Experience tells him that usually a few hour's after such a storm has cleared away nearly every stalk will be found standing up as straight as ever. In reality to have been blown down was perhaps the best thing that could have happened to the plants under the circumstances, for if the lower parts had not given way they might have been seriously injured.

How is this fortunate reeovery accomplished? Again the leaf sheath comes to the rescne. In order to understand just what has taken place, we need to examine with special care the parts near one of the lower nodes. In the oat, for example (Fig. 14 I.), on the outside of the stalk a swollen ring is to be seen (R) whieh at first sight might be taken for a part of the stem at the place of a partition. When, however, we ent through the whole lengthwise, as in Figure 14 II., the ring is found to be situated entirely above the partition, and to constitute in fact the base of the sheath. Even after the sheath is fully grown and has become stiffened as a support for the internode, this ring still retains its original sappy condition. Hence, the base of the slieath is rearly at any time to grow again in case of need. It does grow, and in a peeuliar manner, wheuever the parts are placed in an 
unnatural position. So long as the axis points upwards the power of growth is not awakened; but let it point for a while in any other direction and the undermost part of the ring is stimulated to elongate.

This one-sided growth produces a bend in the stalk where the ring eomes. The stem at this point, following the same eurve as the sheath ring, eauses the parts above to come gradually into an upright position. That is to say, the stalk rises as if by a self-acting hinge. Figure 14 III. shows part of an oat stalk which has become erect in this way. All corn plants, at least when their stalks are growing vigorously, have much the same power of recovery from the effects of violent storms. With maize, however, there is this difference, that insteal of having a sheath ring play the most important part in bending the stalk, it depends in this matter mainly upon its stont lower internodes. These retain for a considerable time the same power of eurving in ease of need as displayed by a sheath ring.

\section{Defenses agrainst Drought.}

Rainstorms, for all their violenee, are not so lard a trial for field plants as clrought. It has been estimated that wheat, muler ordinarily favorable conditions, absorbs from the earth, and transpires, or hreathes out through its foliage each day, an anount of water about equal to the weight of the plant. In an acre of wheat, during the course of the growing season, this womld mean a loss of two hundred and fifty tons. Long continuanee of dhy wind and hot sun, by promoting loss of moisture from the foliage, would increase very much the amount thus withdrawn each day. At the same time, the supply of rain liav- 


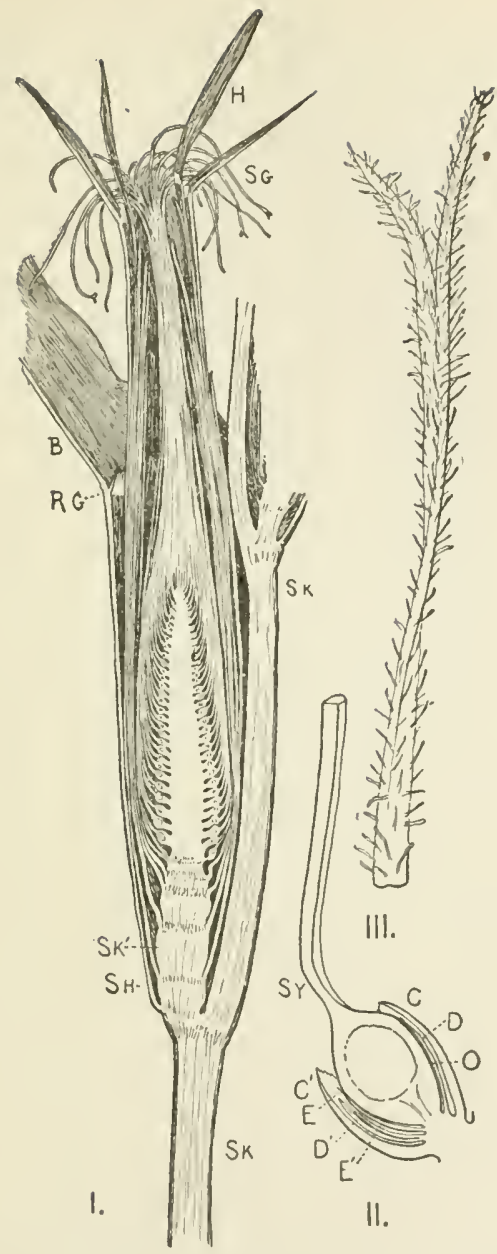

Fro. 8. Maize. I. A young ear cut through the middle lengthwise. Sk, Sk, the main stalk; Sk', the branch stalk which hears the ear; $\mathrm{SH}$, sheath of the leaf infolding the wlole ear; R G, rain guard; $\mathrm{B}$, bhade of the same leaf; H, husks; So, stigmas ("silk") protrulling beyond tlie husks.

II. A single spikelet of the ear, showing the bracts $\left(C, C^{\prime}, D, E, D^{\prime}, E\right)$ and the ovary $(O)$ and lower part of the style (SY) of the single pistil. Fularget.

III. Upper part of stigma, showing the delicate hairs thitt cover it. Enlarged. 1Origimal.) 
ing eeased, there would be less and less moisture to draw from in the ground. We know that the growth of plants is retarded if their aetive parts are deprived of even a small share of the large amount of water they ordinarily eontain; while if the amomnt be much decreased they die. It thus appears that drought offers a most serious problem to plants of the ficle. There are two ways open to them for meeting the diffienlty; they may extend their roots as far as possible into the deeper and moister layers of the soil, or they may in some way check the loss of water from their leaves. Corn plants to both.

The depth to which the roots of eereals will sometimes penetrate is not a little remarkable. No true idea of their full length may be gained by simply pulling up the roots from the soil, for they are so slender as to be easily broken far above the tip. The most satisfaetory way is that deseribed in the following account of observations carried on by a German botanist: "An excavation was made in the field to the depth of six feet, and a stream of water was directed against the vertical wall of soil mitil it was washed away, so that the roots of the plant growing in it were laid bare. The roots thus exposed in a field of rye... presented the appearance of a mat or felt of white fibres, to a depth of about four feet from the surface of the ground. The roots of winter wheat ${ }^{1}$ he observed at a depth of seven feet, in a light subsoil, forty-seven days after bowing." 2 Such deep

1 The name "winter wheat" is applied to those sorts which are sown in the fall, live over the winter, and ripen the following season. "Spring or summer wheat" is planted in the spring, and harvested before eold weather.

2 Johnson's How Crops Grow. 
penetration of the parts through which absorption takes place cannot fail to give to these plants a great advantage in times of drought.

Yet even the reserve supply of water in the lower layers of the soil would soon become exhausted if transpiration from the leaves went on as freely as under ordinary circumstances. This deep-lying water is the plant's last resource. Hence the special need for stringent economy of this reserve, by checking as much as possible all needless transpiration. We know that the loss of moisture from any part depends largely upon the extent of surface exposed to the surrounding air. A comparison of wheat plants from dry and from moist localities has shown that leaves of the former are narrower than those of the latter, of the same length, thus giving a helpful reduction of leaf surface in the drier localities. Perhaps a similar eomparison of other corn plants from like localities might show similar difference in the leaves. It is not possible, however, for corn plants to have their leaf-blades much narrower than they generally are, without at the same time losing much of the benefit which comes from good exposure to sunlight.

What these plants need above all for safety and success in the field is some means of changing the form of their leaf-blades at different times. Only thus ean a corn plant avoid the dangers of over-drying at one time, and yet at another time be able to take full advantage of the sunshine. Fortunately just such a ready adjustment to varying conditions is made possible by the easy change from the expanded to the tubular form of blade. It will be remembered that the leaf-blades in all cereals, so long as they are young and so in special danger of wilting from too rapid 
transpiration, retain the tubular form, and thus expose only a small portion of their surface to the drying action of the air. Yet even after they have become full grown and flat, the blades seem never to forget how well the earlier form had served their needs; for whenever it becomes necessary to check waste of moisture, the blade assumes once more as nearly as possible the form it had when young. That is to say, the edges roll inwards so as to cover the upper surface, and in some instanees overlap in order to reduce still more the amount of surface exposed. In the ample leaves of maize not only do parts of the edge roll inwards, but the two halves of the blade fold together as if hinged at the midrib. Among farmers this "curling of the corn" is recognized as one of the most signifieant signs of droight.

Minch the same tubular rolling of the lcaves may be seen also in pasture grasses under similar eireumstanees or when the plants are being dried for hay. In all eases, when there is again sufficient moisture, the blade becomes flat as before. This power of resuming the expanded form promptly on the return of favorable conditions is, as we have seen, scarcely less important than the power of "curling." We know that the great work of food-making, which is what leaves are chiefly for, ean be done to best advantage only when the blade is provided with plenty of moisture and spread ont to receive the rays of the sun.

\section{Food-making and Growth.}

Food-making is the main purpose of the plant during what we may eall the youthful period of its existence. To this end all the parts coïperate from the begiming. Some of the parts help by getting the 
necessary raw materials from the earth and air. Other parts serve by bringing these materials together in the foliage. Here the green parts use the power of sunlight to make over these crude substanees into food in a way that only green plants can do. Finally there are other parts which carry off most of this precions product, in the form of a nutritious sap, to those portions of the plant which are actively engaged in building new structures or at least in doing other work than food-making. It is true that much of the inner workings of these various parts we can ouly guess at, for the plant is like a factory with the diseouraging sign "no admittance." Yet even such general results of the work as may be seen from the outside are enough to show us that the whole is run on a singularly perfect system. There is no liding the fact that so long as the plant is young there is a rapid growth of the organs which are especially concerned in making food, namely, the roots, stems, and leaves. We find, also, that the plant makes provision, as early as possible, for avoiding or repairing injury to those organs from wind, rain, or drought. Thus we may see that our self-builling food-factory is governed by advaneed business methods. From the start, the poliey pursued is to devote at once as much as possible of the product of mannfacture to building additions to the establishment and to insuring its future safety. It is as if there were a wise and enterprising manager in charge of its affairs.

The same spirit of enterprise which learls these plants to take fullest advantage of their opportmities appears also in the establishment of what we may call "branch factories." That is to say, uncler favorable circumstances, extra stalks are developed as out- 
growths from near the base of the main stem. (See Figures 12 and 13.) These additional stalks are called "tillers." Each may grow into a leafy grain-bearing shoot like that from which it sprang. Each, moreover, sends out its own set of roots which enable it very soon to obtain for itself the necessary materials from the soil withont depending upon the supply absorbed by the main roots. So complete is the independenee thus secured that even if the connection with the main stem should happen to be severed the new branch ean live on vigorously as a separate plant forming tillers of its own. This liabit of tillering is especially well shown in wheat, oats, and rye, which not uneommonly produce as many as twenty stalks or more from one.

At the Botanie Garden in Cambridge, England, an experimenter who was eurious to see how far this power might be taken advantage of to increase the yield from a single seed made the following trial. A kernel of common red wheat sown in June was found in August to lave produced a plant so well tillered that it conld be divided into eighteen separate plants. These being transplanted to give room for further development were found in the autumn to have branched so freely as to permit dividing them again into sixtyseven plants. After resting over the winter they resumed their vigorous growth in the spring, and tillered so well that a third division gave five huncled plants. 'These being transplanted were allowed to remain undisturbed nutil harvest. when it was found that some had producel orer one hundred grain-bearing branches. Altogether, there were 21,109 heads yielding forty-seven pounds, seven ounees, of elear corn, or about 576,840 kernels as the product of a 


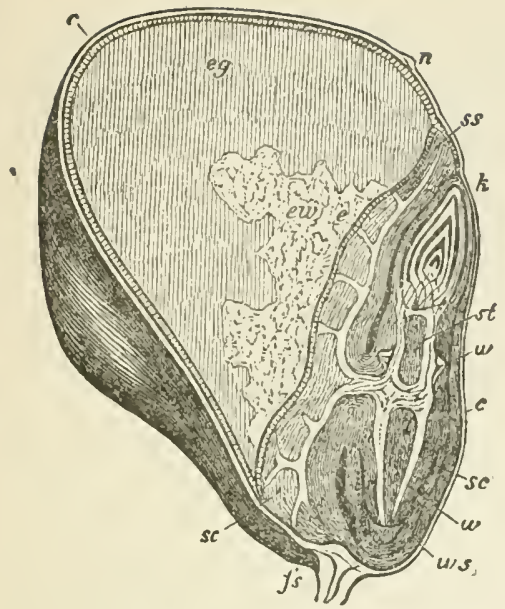

Frg. 9. Maize, a ripe kernel cut lengthwise through the germ. $c, c$, the outer layer or "hull"; $n$, the base of the style; $f s$, stalklet; eg, hard, yellowish part of seed food; elc, whiter portion of seed food; $s c, s c$, scutellum of the germ; $s s$, its point; $e$, its skin; $k$, the leaves of the germ packed closely in a bud; st, stem-part of the germ; $w$ (below), the main root protected by a special covering or root sheath (uss); $w$ (above), secondary root. Enlarged about 6 diameters. (Sachs.)

Frg. 10. Maize, kernels sprouting.

I. Kernel seen from the germ side. The main root (w) has just broken through the root sheath (ucs). $k$ shows where the young leaves and stem are still incased, and $e$, the part of the kernel where the food is stored. $A$, the germ removed, showing in front view the scutellum (sc) broken througly and the margins of the rift $(r, r)$ spread apart. $\quad B$, the same in side view.

11. The same as I, further adranced, showing, besides the more elongated root, the leaf cylinder (b) protruded beyoud the covering (l), which it has pushed aside.

11I. The same, still further advanced; side view. $b^{\prime}, b^{\prime}$, young leaves; $w^{\prime}, w^{\prime \prime}$, $w^{\prime \prime \prime}$, sccondary roots. Natural size. (Sachs.)

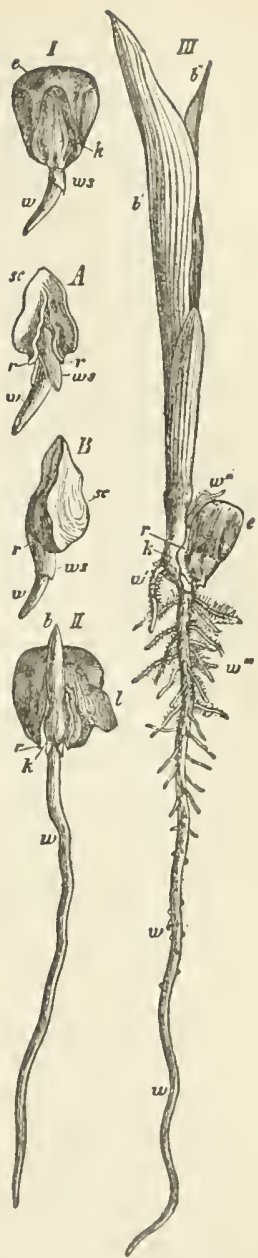
. 
single seed. The gardener believed that if he liad divided the plants once more in the spring (as he lad done successfully in a previous experiment) the yield would have been increased fourfold.

\section{How Corn Plants provide for their OfFSPRING.}

So far as we have yet considered the life of corn plants, we have found them devoting their energies mainly to the making of food. The only use we have seen the plant make of this food is the building of additional food-making parts. Of course such increase of facilities for food-making cannot go on indefinitely, even though the tiller-branches become separated as independent plants. Sooner or later every individual plant must die. Hence the necessity for providing some means of starting new plants like itself. In corn plants the life of the kind is continued from generation to generation by means of seeds containing the beginnings of offspring. To produce such offspring and provide for their welfare becomes thus the final duty of the plant.

\section{Seed-making.}

Just as soon as its food-making arrangements are in good rumning order, the plant begins to devote a share of its surplus to the formation of new parts especially fitted to bring the seeds to perfection. These new parts develop more and more rapidly as the season advances, and so consume a larger and larger share of food, until finally, as we shall see, they take up about all the plint can make.

The parts which are especially concerned in perfecting the seeds present some interesting differences 
from the parts we have already examined. This we should expect, in view of the very different kind of service they have to render. We shall find, also, that they show some significant resemblances to those other parts, as if old forms had been, in a way, made over for new uses. Before we can well understand how the new parts serve their purpose we must carefully examine their peculiarities.

\section{The Floral Purts.}

If we examine a corn plant soon after the last leaf has appeared, there will be seen peeping out from its protecting folds a crowded cluster of numerous, small, delicate parts which, upon further growth, are found to be grouped into clusters of clusters. (Figures 12, 13, and 16.) This compound cluster constitutes what botanists eall the inflorescence or floral portion of the plant, although it must be almitted that the flowers which it includes are very different in appearance from what are ordinarily so called. They agree with other flowers, however, in producing seeds. When this is accomplished, the inflorescence becomes the "head" or "ear" of grain. All the different corn plants agree in having the inflorescence borne at the top of the stalk as a termination to its growth.

Perhaps the most striking lifference among grain plants is that which distingnishes the floral elusters of maize from all the others. As will be seen from Finures 12, 20, 23, 25, and 28, wheat, rye, barley, oats, and rice, have in each case but one sort of infloreseence, while maize (Fig. 3) has the two sorts ordinarily known as the "tassel" (T) and the "ear" (E). Moreover, the ears of maize appear as outgrowths from the side of the corn stalk, and this may seem to 
contradiet the statement made above that the flower clusters of cereals always terminate the stalk. In this respect, however, these ears do not really differ from the terminal clusters borne by the tiller-stalks of this and other grains. If we eut down through an ear, as shown in Figure 8, we find that it is borne on the end of a stalk which is essentially like that of a tiller except that the ear-branch arises further up on the main stem and is shorter. Yet for all that, the number of internodes is abont the same as in the main stalk.

One marked result of the way in which the stalk of a maize ear is shortened appears in the erowding of its leaves. Along with this goes a change in form which fits them for serving as husks to protect the tender parts within. It will be remembered that so long as the whole branch is tender, and thus in need of protection, it is completely covered by a leaf sheath belonging to the main stem. As the husks elongate, their upper parts emerge from the sheath and the ontermost husks spread their blades on either side. In comparison with the leaves of the main stem these onter husk leaves are seen to have a smaller blade and rain guard, but as large a sheath. If now we compare with these onter husks the ones which they inclose, we find that both blade and rain guard become smaller and smaller as we proceed inward until finally we find nothing lout pale, papery sheaths with no trace of blade or rain gnard whatever. This gradual series of forms helps us to see that eren the innermost hnsks, although so unleaflike in appearance, are really leaves. Moreover it is plain that sinee they are destined to remain entirely eovered by the outer husks, these inner wrappers could make no use of 
either blade, rain guard, or the green coloring-macter of foliage. Hence there is no occasion for their being more leaflike than they are.

Leaving the other parts of the maize ear to be considered presently, let us now see what may be found in the flower clusters of the other cereals. We will begin with the floral parts of the oat (Figs. 16 and 17 ) as affording a good standard with which to compare the others. As already observed, the upper part of the main stalk is continned into the inflorescence, where it gives off several branches which bear the little elusters or spilielets. (B, Fig. 16.) The spikelets consist of a few parchment-like, sheatling organs (snggesting miniature husks) inclosing tender parts within. In fact it is chiefly in size that these little husks differ from

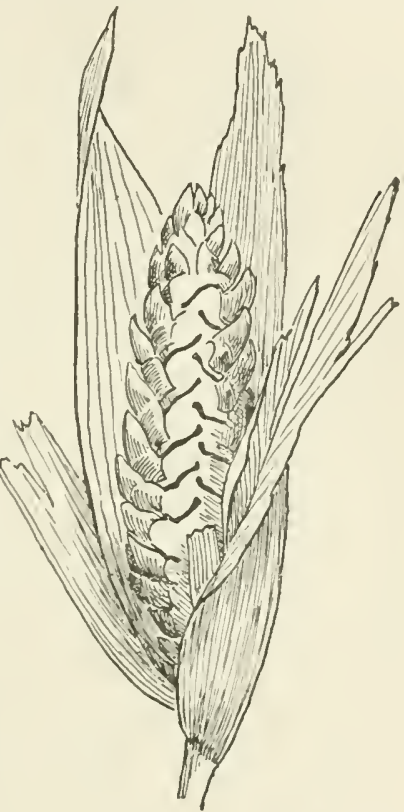

FIg. 11. Coyote corn, from Mroro Leon, Mexico. An ear (natural size) with husks partly removed. The rachis or cob, when ripe, breaks readily into separate sections. (Drawn by the autlor from a specimen in the Herbarium of Harvard University.) the large ones of maize.

The husks of both must be looked upon as leaves of the flower cluster which differ from foliage leaves mainly in such particulars as fit them for the special service they have to perform. Leaves which are thus 
peculiarly developed in connection with a flower cluster are called bructs. The outermost bracts of the oat (C, Figs. 16 and 17), like the inner luusks of maize, consist wholly of what corresponds to a leaf sheath. Commonly one or more of the inner bracts of the oat (D) resemble the outer ones of maize in having also a part corresponding to a leaf-blade which here takes the form of a slender projection (B, Fig. 17). This delicate outgrowth is called an $a w n$. It is the development of such awns that gives nis the "bearded" varieties of grain. In the oat, as will be seen, the awn stands out from the sheath at an angle much as a blade does. The sheath, moreover, is prolonged beyond the base of the awn, thus taking the place of a rain guard. We ean hardly suppose, however, that this part of the oat bract is of much use in keeping out the rain.

When the plant is in bloom the bracts spread suffciently to allow certain parts of the flowers they inclose to push out into view. ( $B$, Fig. 16.) From each flower appear three little donble sacks. the anthers, each borne on a slender thread, the filament; and two small feathery affairs called the stigmas. If we cut such a spikelet in half from the stalk up, as shown in Fig. 17, the innermost floral parts may be seen also. In the centre of the flower we find a romided body, the ovary (Or), which is a thin-walled case containing a tiny egglike structure, the orule (OL), that ripens into a seerl. Each stiyma $\left(S_{G}\right)$ is connected with the ovary by a short stalk known as the style (Sr). Of these there are two to an ovary, as shown in .J, Fig. 16: styles, stigmas, and ovary taken together form the pistil of the flower. Outside of this come the filuments (F, F', Fig. 17) each bearing 
an anther ( $\mathrm{R} \mathrm{A}, \mathrm{R}^{\prime}$ ), from which when mature there may be shaken out through special openings innumerable yellow, dustlike particles called pollen (P). A filament with its anther make up a stamen. At the base of the flower is a pair of minute scales, the lodicules (G, Figs. 16 and 17), which are of use in pushing apart the bracts so as to expose the anthers and stigmas when the proper time arrives. All these floral parts are shown at an earlier stage of their development in the younger unopened flower $\mathrm{Y}$, Fig. 17.

There remains to be mentioned only one more portion of the oat spikelet. This is a pair of very small bracts ( $\mathrm{R} \mathrm{F,} \mathrm{Fig.} \mathrm{17)} \mathrm{borne} \mathrm{at} \mathrm{the} \mathrm{tip} \mathrm{of} \mathrm{the} \mathrm{little}$ rachis $\left(R^{\prime}\right)$. If we separate these tiny bracts there is found to be no flower within. We may regard them as indicating the place where a flower might have been expected but where none is developed.

A comparison of the inflorescences of the other cereals (Figs. 4, 8, 21, 23, 27, and 30) with the flowering portion of the oat will show that in spite of more or less striking differences of detail the general make-rp is very much the same in all. That is to say, all have the same floral parts inclosed in bracts which may be readily recognized as such, although differing often considerably in size and form.

The reader may find it of interest to notice the following peenliarities which serve to distinguish the different kinds of corn plants when in blossom. Attention has already been called to the fact that maize has two sorts of inflorescence, the tassel and the ear, while in each of the other cereals there is only one sort of inflorescence. Of these latter, oats (Figs. 12, 13 and 16) and rice (Figs. 20 and 21) have their 
spikelets borne on rather long slender stalks, forming thus a loose open eluster; while rye (Figs. 23 and 24, $B$ ), wheat (Figs. 25-27), and barley (Figs. 28-30), have their spikelets very short-stalked and crowded, thus forming a compact spike or "head." Rice differs from oats in having, instead of several flowers within each spikelet, only a single flower which is like those of the oat except that it has six stamens, and has the awns when present borne on the very tip of the bract. (See Fig. 22.)

In rye, wheat, and barley, the awns when present grow like those of rice, from the tip of the bract, and being close together give the beautiful "bearded" appearance to the spikes of these grains. There results also from this crowding of the spikelets the eurious flattened and zigzag form of the rachis or "backbone" of the spike shown at R, Fig. 27. Rye and wheat agree in having a single spikelet produced at each node of the rachis (Figs. 24, B, and 27, $A$ ), and in that partieular they differ from barley, which has three spikelets at a node. (Fig. $30, B^{3}$.) Rye has two flowers in each spikelet. Wheat has several flowers in each spikelet except a few of the lower ones, which are very small and flowerless. (See Figs. 25 and 26.) Barley has a single flower in each well-developed spikelet (see Fig. $30, \mathrm{~B}, \mathrm{~B}^{1}$ ), but of such spikelets there may be only one or two in each group of three; in that ease the other spikelets are flowerless and appear in rows from top to bottom of the spike. (Fig. 29.) Some kinds of barley have part of their flowers containing stamens but no pistil.

All the flowers of the maize tassel are like those of the barley just mentioned, in having stamens alone. (Fig. 4.) The ear of Indian corn is an enormously 
developed spike bearing a large number of spilielets, in each of which a single pistil is produced, but no stamens. (Fig. 8, I. II.) The pistil differs from those of the other cereals chiefly in having an exceedingly elongated style and stigma ( $\mathrm{S}_{\mathrm{G}}$ ) which form the "silk" of the ear. The bracts belonging to these hidden flowers of the maize ear are very delicate (II. $\mathrm{C}, \mathrm{C}^{\prime}, \mathrm{D}, \mathrm{E}, \mathrm{D}^{\prime}, \mathrm{E}^{\prime}$ ), and form the thin papery chaff which remains attached to the cob when the kernels are removed.

From what has been said of the flower clusters of the various cereals, it will be seen that however much the parts differ in minor details of structure and arrangement, they are all built upon essentially the same plan, although there is more or less modification according to need. This fundamental plan may be expressed in a general way as follows: the flowers consist typically of three stamens and a single pistil, although sometimes the number of stamens is doubled, and in other cases, either stamens or pistil, or both, may be wanting. Around these floral organs are protective bracts or inflorescence leaves, which may be more or less unleaflike in form, but which are like the other leaves of the plant in being arranged in two ranks on opposite sides of the stem which bears them. In having their flower clusters constructed in this way corn plants resemble the familiar wild grasses of pasture and meadow. Indeed, most of the features of strncture we have described as belonging to cercals, and much of what we have still to consiller, are found also in these other plants. Botanists recognize the closeness of this resemblance by including cereals among the members of the "grass family." This is as much as to say that the cereals are grasses which 
have come to be cultivated especially for their edible grains, much as " herd's grass" has come to be raised for its herbage.

\section{The Beginning of the Seed.}

Our study of the floral organs of corn plants has now prepared ns for considering the question as to how these parts act together for the perfecting of seeds. If we ask why it is that so many parts are developed for this purpose, and why they are so strangely complicated in structmre, the answer is that all this elaborate preparation contributes to the welfare of the plant's offspring. It is now known to be a great benefit for offspring to have when possible two parents, so that advantageous characteristics inherited from each may be combined. This key enables the botanist of to-dlay to unlock some of Nature's secrets which have baffled mankind for ages.

We have seen that an ovary contains an ovule ready to grow into a seed. It does grow provided some pollen from a plant of the same sort falls upon the stigma; otherwise no seed is developed. Hence, if a farmer shonld go through his maize field and cut off all the tassels as soon as they appeared, he would find the ears at harvest time sadly lacking in kernels. How it is that pollen resting npon the stigma is enabled to coöperate with the ovnle in such a wonderful way would reqnire many pages to explain. For our present purpose it is sufficient to know that a single pollen grain so placel does bring about in some way the development of the ovule into seed, and that the seed so prodneed is eapable of becoming a plant which will inherit peculiarities not only from the ovule-bearing parent, but from the pollen-bearing 
one as well. It may happen that the pollen affecting the ovule was prodnced by the same individual plant that bears the ovule. In that ease we have what is known as close-pollination. When the pollen of one individual is carried to the stigma of another we have cross-pollination.

Careful experiments have shown that, at least in the long run, the offspring resulting from cross-pollination are in many ways better plants than those produced through close-pollination. It is mainly for the purpose of securing to the offspring the important benefits of cross-pollination, or, as we said before, the advantage of having two parents, that corn plants develop such elaborate floral arrangements. For the accomplishment of this purpose, as we shall now proeeed to show, they take advantage of the carrying power of the wind, thus making a servant of what was before an enemy.

Indian corn affords a particularly fine example of cross-pollination through the ageney of the wind. The stamens held high in the air extend their anthers on slender threads well beyond the bracts. When fairly out, each pollen-sack, as shown in Fignre 4, opens by a little hole at one side of the lower end. The arrangement is such that the elosely packed dustlike pollen is held in readiness to be shaken out in small quantities by every passing breeze. At the same time, the particles are not so likely to fall in still air as if the opening were at the very bottom. If the pollen did fall directly down, it would either be wasted or else reach the stigmas of the same plant, and so effect close-pollination. Once confided to a current of air the pollen will be wafted sideways for a greater or less distance according to the strength of the current, 
until finally, having meanwhile sunk a fer feet below the former level, some of the pollen grains may be blown against the long silky stigmas protruding above the husks of a young maize ear perhaps rods away. The pollen-grains would then become entangled among the slender hairs which eover these stigmas (see III. Fig. 8), and cross-pollination would be accomplished.

It has been admitted that the pollen of a maize plant may sometimes fall in still air npon its own stigmas. But there are two reasons for believing that this searcely ever happens. In the first place, as we have seen, the anthers are so construeted that a breeze is generally required to shake ont the pollen, and a breeze will earry the pollen away. In the second place, we find that, as a rule, the stigmas of the plant are not in readiness to reeeive pollen until after its own anthers have been emptied. Close-pollination is thus as mlikely to oceur, as it is likely that erosspollination will be secured.

Of course not all the pollen from a maize plant can be expeeted to find its way to maize stigmas in just the right condition to reeeive it. On the contrary a very large share must inevitably be lost. To make up for this a eorrespondingly large amount of pollen is produced. According to a careful estimate an average maize plant has seventy-two hundred stamens, eontaining about eighteen millions of pollen-grains. Since abont two thousand ovules are reckoned to a plant, this would give nine thousand pollen-grains to an ovule. When it is remembered that a single grain falling upon a stigma is sufficient to insure the ripening of the ovule, we see that a very generous margin for mislraps has been allowed.

The provisions made for pollination in wild oat- 
grass (Fig. 31) are very like what are found in most grasses, and are of interest for comparison with those of cereals. The stigmas of a given flower eluster may or may not be protruded while anthers of the same cluster are shedding their pollen. In either case, however, there is a good chance that cross. pollination will be accomplished throughout most of the cluster, and that in one way or another all the stigmas will receive pollen even though it will be partly from the same plant. Such plants go on the prineiple that while cross-pollination is worth making a good deal of effort to obtain, it may sometimes prove impossible (as in the absence of neighboring plants of the same kind), and then closepollination is much better than no pollination at all.

Among such grasses as the cereals, where innumerable individuals conmonly grow close together in the same field, we ean-

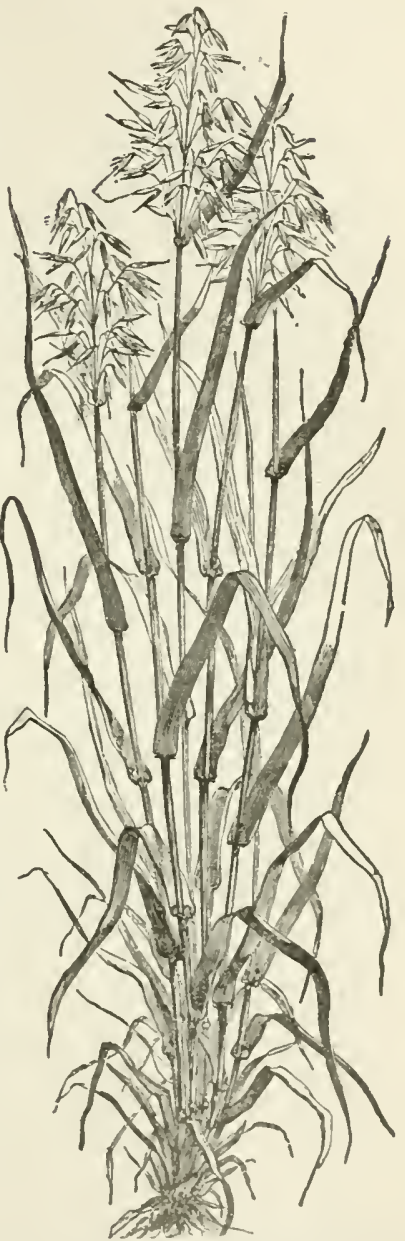

Fro. 12. Oat plant, showing general appearance after several tillers have formed. (Baillon.) not of course suppose that any plant would be likely 
to suffer from the lack of neighbors. It is not impossible, however, that rain coming at the wrong time, or some other unfavorable circumstance, might largely defeat " the best laid schemes" for eross-pollination. Indian corn, as we have seen, protrudes its ample stigmas all at once and far beyond the husks. So long do they remain thus exposed and in good condition for receiving pollen, that even if bad weather lasted some days, there would be plenty of time left for thorough pollination. Other cereals, on the contrary, open their spikelets only a few at a time and close them again after a brief exposure of the stigmas and anthers. This is donbtless necessary because of the greater delicacy of the parts. It makes the flowers, however, much more dependent upon favorable weather to accomplish their cross-pollination. Indeed, it must often prove to be impossible with many of the flowers. Hence, if the ripening of seed in these plants were made to depend entirely upon the chances of securing a cross (as is the ease with eertain linds of grasses), then the farmer's erop would be very likely to suffer. Cultivators of grain naturally prefer those sorts which give the best yield. This means that the varieties which best provicle for the certain pollination of every ovule are the ones most generally selected. The result is that we find in many of the cereals in cultivation as good or even hetter provision for close-pollination than for securing a transfer of pollen from plant to plant.

In rye the stigmas and anther's mature at the same time, and as the bracts then open willely, al good opportunity is given for either cross- or close-pollination. The amount of pollen is certainly sufficient, for it has been estimated that a single anther contains twenty thousand of these golden dustlike grains. This makes 
something like two hundred pounds of this powder to an acre of rye.

The arrangements for pollination in wheat, barley, oats, and rice are much the same as in rye, except that their bracts as a rule open less widely and in some cases not at all. When a flower remains closed its pollen can reach no stigma but its own, and cross-pollination is prevented. Yet it is a curious fact that in such cases there is still an enormous amount of pollen. Since we linow that a single particle of pollen to each ovule is sufficient to insure its proper development, all this unnecessary production of precious material seems strangely wasteful. We can account for it only on the supposition that these flowers were originally fitted for cross-pollination and have lost the power through many ages of cultivation.

The loss of this important power may have come about partly through the continued sclection of the sorts which yielded best, as already suggested. Perhaps it may have resulted in part also from the special care which these plants have received for centuries. At least it seems not improbable that plants which are made to grow in soil carefully prepared and enriched would have less need of the advantages of cross-pollination than wild plants which have to shift for themselves. However this may be, we must not argue from the facts given that eross-pollination is of small value to the offspring even of cultivated plints. Indeed we have abundant proof to the contrary in the fact that varicties most highly prized by modern cnltivators - as, for" example, the famous "pedigree wheats" - have been obtained through repeated crosspollination by artificial means. The truth would seem to be that farmers are in some cases willing to 
forego certain advantages for the sake of securing others which they deem more important.

\section{Ripening and Protection of the Fruit.}

After pollination has been effeeted in one way or another, the stigmas and anthers, having now fulfilled their purpose, fall off or wither. At the same time the ovary and the ovule inclosed within it begin to undergo the remarkable changes which constitute the ripening of the grain. Nearly all the food which the plant now manufactures or has previously stored in its pithy parts is heneeforth delivered to this region of rapid growth to serve as material for the transformations in progress.

What goes to the ovary wall enables it to enlarge so as to keep paee with the young seed within. The main bulk of all the food, however, is needed in the ripening ovule, or seed that is to be. As the material arrives part of it is used up at once in the formation of a little plant with tiny stem, leaves, and roots. These are all paeked into the smallest spaee, and the whole comes to oceupy a position at one side near the lower end of the seed. (Fig. 9.) The larger share of the material received is stowed away in the remaining portion of the seel, as food for the young plantlet to use at the time of sprouting.

Sinee in the plant hody materials may be carried from place to place most readily when dissolved in the sap, the food substances which come to the young seed arrive in liquid form. Here we find them acenmulating for a while, as constituents of a sweet milklike fluid. While in this stage, the kernels are said to be "in the milk." Gradually the nutritive part of this "milk" separates from the watery portion, some- 
what as curd separates from whey. At the same time fresh nutritive material is arriving to be solidified in the same manner. Finally the "milk" is entirely replaced by solid food-material which becomes in the ripened grain as hard as the hardest cheese. Thus in each seed there is packed the largest amount of food possible in the a vailable space.

During the milky period in the ripening of the grain, the sweet and exceedingly tender kernels offer a great temptation to certain birds. Rice planters are especially troubled by hosts of bobolinks which arrive from the north just in time to do most damage in the fields. No longer the conspicnonsly colored songsters we know in summer, these birds have now become sparrowlike in appearance, and, as a result of their gluttony, almost too fat to fly. While in this condition, they are known as "rice-birds," and appear under that name as a delicacy in the markets. Pictures from Japan indicate that a similar bird infests the rice-fields of that region. Wheat and other grains are also known to suffer somewhat in the same way in various localities.

It has been observed that the bearded varieties of grain plants suffer less from the attacks of birds than do the awnless sorts. Henee, it wonld seem that awns may be the means naturally provided as a protection against these enemies. An examination of a well-developed awn of rice, rye, wheat, or barley will show it to be especially well constructed to serve as a defensive weapon. (See Figs. 22 and 24 D.) Not only is it sharp at the tip, but along the sides it is armed with numerous upward pointing teetls. The whole reealls the long saw-edged spears used by certain savage warriors. A little bird with short bill in trying to steal 


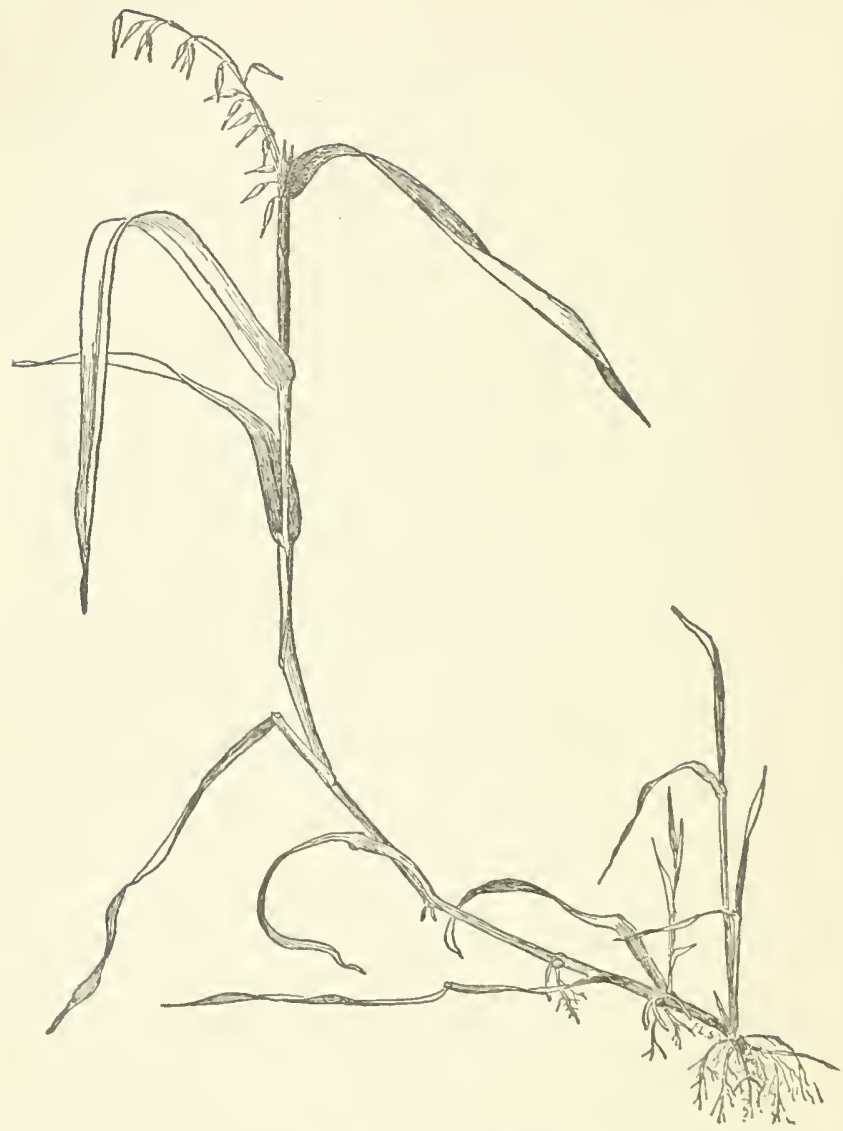

Fra. 13. Oat plant which had been blown over and then recovered the npright position of its upper part by bends at the nodes. Brace roots are dereloping from the lower nodes, and two tillers have started near the base. The young intlorescence is just pushing its way out from the uppermost leaf shenth. (Original.) 

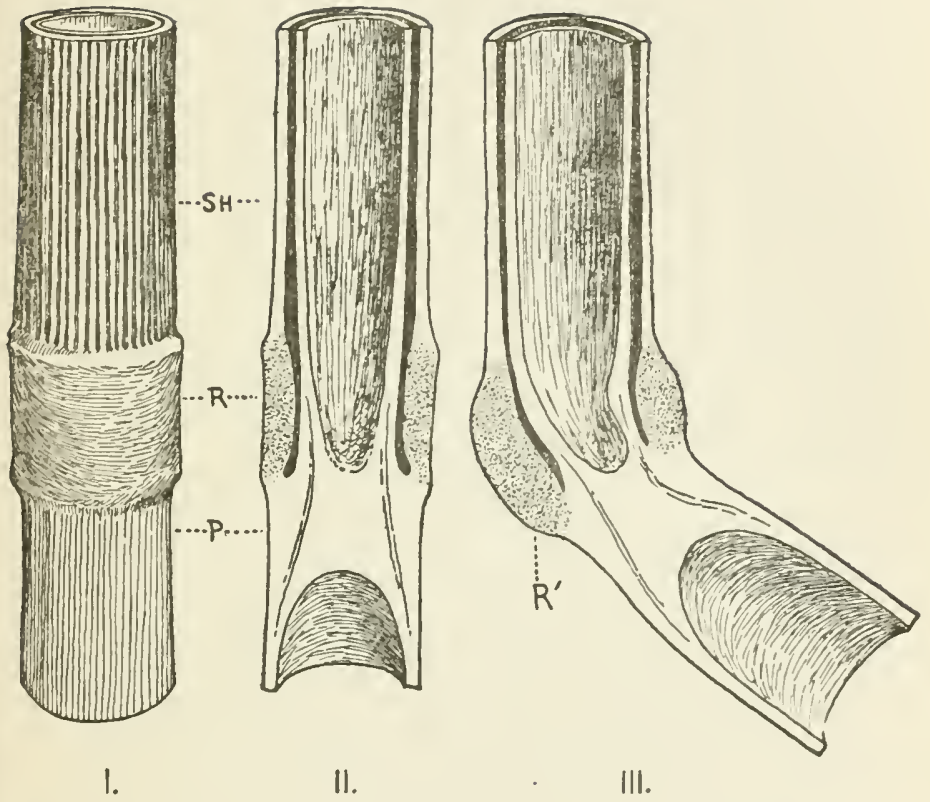

Fio. 14. I. Part of an oat stem showing swollen ring (R) at base of sheath ( $\mathrm{SB}$ ). $P$, place of the node. (Enlarged.)

II. The same, cut lengthwise.

III. The same, after the upper internode has been bent into an erect position from an oblique one by growth of the sheath-ring on its lower side $R^{\prime}$. (Original.) 
the kernels from a bearded spike of wheat, rye, or barley, could hardly avoid rubbing tender parts of its head against the sawlike edges of many awns. The entire absence of such defensive weapons from maize may doubtless be accounted for by the fact that its thick husks generally afford ample proteetion.

It must be remembered that whatever food-material goes to the building of awns is just so much taken from the store which otherwise might be laid by in the seeds. This may in part account for the fact that some of the best-yielding varieties of wheat, and the like, are entirely without awns. (Fig. 26.) In regions where birds woukd do little damage, or where they may be readily seared away, it is natural that farmers should encourage those varieties of grain which make less awn and more seed.

The ripened grain or kernel of any corn plant, as we have seen, consists of the enlarged ovary completely filled by a single seed. It is thus not merely a seed, but a seed and its case. The seed case, moreover, fits so tightly around the seed, that the "seed coat," or outer layer of the seed, unites with the ovary wall to form a hard, protecting layer or "hull." In the process of milling this indigestible part is separated and forms the main bulk of "bran," while the seed food is ground into meal or flour.

Sometimes as in oats (Fig. 18) and common barley, the precious eontents of the grain are still further protected by having one of the innermost bracts of the spikelet wrapped so tightly about the seed case as to seem almost a part of the kernel. In riee two hard bracts inclose the ripened grain and fall off with it. These coverings are of speeial nse after the grain has left the parent plant, and must shift for itself. 


\section{Scattering und Planting of Seeds.}

With grasses that grow wild, the future welfare of the offspring depends largely upon the seeds being carried to some new locality. For, plainly, if the seeds should sprout in the immediate vicinity of the parent, the young plants would have to live upon soil from which the substances most needed for their growth had already been largely exhausted. Let them be carried to a distance, however, and there would be a chance of their securing a more favorable place of growth.

In order to obtain this benefit for their offspring, wild grasses provide various means for securing the transportation of their ripened seeds. Some of them develop tufts of hair, long streamers, and balloonlike coverings, or other special arrangements for catching the wind. Aquatic grasses provide a boatlike affair in which the seed may float away. Certain land forms have hooked or barbed projections on bracts surrounding the seed, which make thus a sort of burr. This, catching into the fur or fleece of a passing animal, may be earried a long way before it is rubbed off. Still other methods might be mentioned by which different wild grasses send their seeds on a journey, but enough has been said to show that this important provision for their welfare has by 110 means been neglected.

When we turn to our cnltivated cereals and ask what arrangements they have for dispersing their seeds, we find that in this matter they present a marked eontrast to the other grasses. Instead of taking advantage of the carrying power of wind, water, or passing animals, they generally seem to be 
doing their best to prevent such natural ageneies from removing the seeds at all. The kernels of maize, for example, are attached so firmly to the eob and inclosed so tightly by the husks that considerable manual labor is required to separate them from the

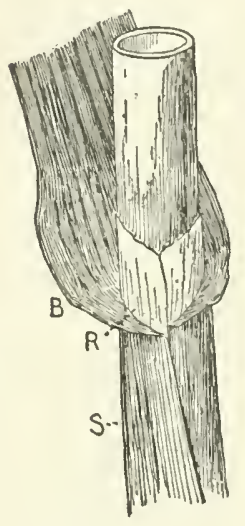

Fig. 15. Oat. Part of leaf and stem showing the rain guard $(R)$ where the blade (B) and the sheath (S) join. (Original.) plant. With the other grains, as we know, severe threshing is necessary to dislodge the kernels from their eoverings. Sometimes this habit of holding their ripened seeds leads to a curious result. If, because of continued wet weather, a farmer is nuable to harvest his wheat or barley, he may find the kernels spronting in the heads, and pushing forth clusters of little green leaves from every spikelet. A wild grass could scarcely be found in such a predicament.

The reason for this remarkable eontrast between wild grasses and those eultivated for their grains is probably not far to seek. We know that a farmer can derive most profit from the sorts which hold their seeds wntil he is ready to harrest them. Naturally, also, he prefers to manage the sowing himself. From the earliest times, therefore, intelligent growers of grain would have been likely to plant only those sorts which hold their seeds long enough for the farmer to gather them, and only these wonld stand any chance of benefiting from human care. Consequently the enltivation of grains must have continually discouraged whatever methods of dispersal these plants may have had in the wild state. It is true that as soon as 
any kind of grain lost the power of scattering its seeds, it became entirely dependent upon man's , care for the continuance of the race. Yet through such dependence it must receive great benefit. Henceforth, upon its welfare would depend in large measure the welfare of man, and consequently it would have bestowed upon it man's intelligent care through which the highest possibilities of its kind would be developed.

Certain sorts of corn plants have come to depend more than others upon human agency for the sowing of their seeds, just as in the matter of pollination the influence of culture lias been more marked in some cases than in others. Thus our maize plants if left to themselves in the field would not produce another crop. The same is true of most sorts of wheat and barley. These plants are known only in the cultivated state, and botanists believe that the original wild forms may have died out entirely. Rice, rye, and oats, on the contrary, often sow their seeds about the fields in which they are cultivated, and in favorable localities they thus establish themselves as wild plants. Our cultivated varieties of oat are believed to be merely improved forms of "wild oat," which grows as a weed in the same fields. This close association of the wild with the cultivated form is accounted for on the supposition that of all the cereals the oat has most fully retained its original power of sced dispersal, and hence is most apt to relapse into the wild condition whenever opportunity offers. Such wild-growing forms of corn plants are of interest as showing us how the ancestors of our cultivated grains used to provide for the planting of their seeds before farmers came to help them.

The fruit of the wild oat mentioned above differs 
from that of the cultivated sort in three partienlars, whereby it takes advantage of the carrying power of wind. Thus, as will be seen by eomparing Figs. 18 and 19, the wild oat has a smaller and eonsequently lighter grain, which can therefore be more easily blown away. Moreover the surface exposed is made larger by the longer and rongher awns and the numerons long, bristly hairs developed on the inner bracts. These peenliarities of the wild plant are plainly the ones which serve for the dispersion of its seeds, and are furthermore just the ones that eultivation would diseourage.

Another peeuliarity of the wild oat is the marked twisting of the awn below the sudden bend. When moistened, the twisted part uncoils; upon drying, it coils again; and this uneoiling and eoiling may be repeated many times. At each eoiling, the free part of the awn is made to sweep around like the hand of a wateh, or, if the tip of the awn is held fast, then the main part of the fruit is foreed to revolve several times on its axis. When one of the separated fruits earried away by the wind falls at last to the ground among grass or stubble, the peculiar movements of the awn help to bury the seed in the soil. 'At the first increase of moisture the awn revolves till its tip is stopped by some stalk or elod ; then the twisting motion is transmitted to the lower part of the fruit, which, being sharp and beset with upward-pointing bristles, slips forward with ease but not baekward even when the motion of the awn is reversed. The result is that with every twist the seed part is foreed further and further into the earth. Country boys have noticed that a ripe spikelet of the wild oat, from the peeuliar features deseribed, bear's a curious resemblanee to an 
insect, not only in general form but also as imitating the struggles of an insect when thrown into the water. This resemblance they take advantage of by using the fruit instead of a fly in fishing for trout.

Rice, as we know, is a plant that grows in the water. We should expect, therefore, that like many other aquatic grasses, it would make use of the floating power of water to carry its seeds to new and farorable localities. If, however, we place some ripe spikelets of cultivated rice in water, we find that all of them sink immediately, except a few which have only imperfect grains within the husks. These exceptions show that if the grains of the other spikelets were not so large and heavy the spikelets would not sink. In wild rice the grains are considerably smaller and lighter, and the husks hold so much air that the ripe spikelets are doubtless able to float. The increased size and weight of the cultivated rice grains are plainly results of cultivation.

Rye, wheat, and barley, which resemble one another so closely in the general form of their spikes, give evidence of having closely similar methods of seed dispersal in the original wild state. In the wild form of rye, the rachis of the spike becomes very brittle at the nodes as soon as the fruit is ripe. The same is true to a slight extent of certain sorts of wheat and barley. As a result of this brittleness, when the spikes are threshed around by the autumn winds, the rachis breaks into a number of short sections each with a single spikelet attached in rye or wheat, or with a spikelet cluster in barley. A wind which is strong enough to break the spilie into sections will have carrying power enough to transport the section, with its seed or seeds, no little distance from the 
parent plant. With enltivation, the raehis would gradually lose its brittleness, and now we find this peculiarity almost entirely absent from the varieties which farmers prefer.

So long as botanists knew of no wild plant closely
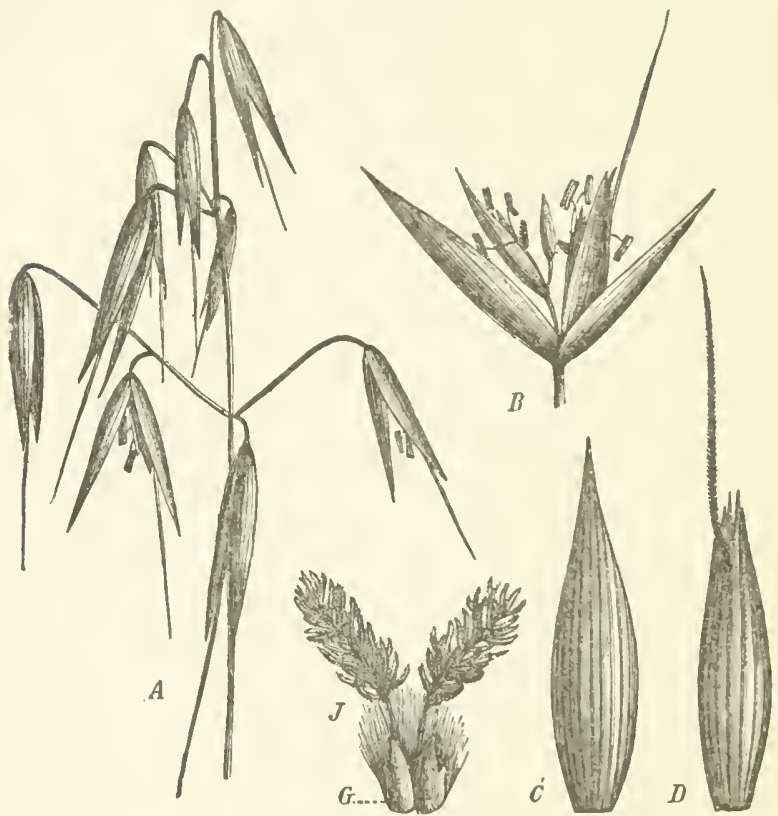

FIG. 16. Oat. $A$, upper part of inflorescence. $B$, a single spikelet in flower, with the bracts spread somewhat apart. $C$, one of the outer bracts. 1 , an inner bract bearing an awn. $J$, pistil. $G$, lodicules. $C, D$, and $J$, enlarged. (Nees.)

resembling maize, it was scareely possible for them to arrive at any satisfaetory idea of the original peenliarities of the fruit, however sure they might be that much ehange had been effeeted by eultivation. Fortunately there was discovered a few years ago, in the 
mountains of Mexico, a wild plant closely resemlling our maize. The Indians eall it "coyote corn," because the eoyotes or prairie wolves are especially fond of it. It is so much like cultivated maize that botanists believe it to be the same or very nearly the same as the wild ancestor of our familiar corn. The most marked difference between the eoyote eorn and the cultivated maize is in the fruit. As shown in Figure 11 , the ear of this wild corn is inclosed in husks like those of eultivated maize, and laas its small pointed kernels borne on a thickened rachis or cob. But this cob is divided into a series of segments by deep cuts extending inwards and upwarls from just below the bases of the kernels. When the fruit is ripe the ear breaks easily into sections in much the same way as the spike of rye or wheat. 'These sections, however, are

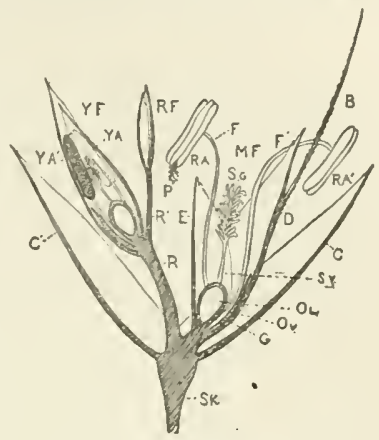

Fro. 17. A spikelet (similar to $B$, F'IG. 16) cut lengthwise to show the inner parts. Somewhat diagrammatic. SK, stalklet; $\mathbf{R}, \mathbf{R}^{\prime}$, its continuation as a little rachis within the spikelet; C, C', onter bracts; $\mathbf{M} \mathbf{F}$, mature flower; Y F, young flower not yet opened; R F, rudimentary flower or pair of bracts with no floral organs within; D, bract with awn (B); E, inner bract; G, lodicule; $\mathbf{F}, \mathbf{F}^{\prime}$, filaments bearing anthers ( $\mathrm{R} \mathrm{A}, \mathrm{R} \mathrm{A}^{\prime}$ ), from one of which pollen is falling $(P)$; So, stigma; $\mathrm{Sr}$, style ; Ov, ovary, containing an ovule (OL); Y A, a soung anther; Y A $\mathbf{A}^{\prime}, a$ similar one cut lengthwise to show the pollen forming within. (Original.)

inelosed by the husks, and so would seem to be prevented from being blown away like the spike sections of the plants mentioned. IIow sliall we aceount for this hincliance to seattering the seeds? Most probably the explanation is this: The husks form a sort of pod, vase-like in form and open above, which holds 
and conceals the loosened sections of the ear. A wind just strong enough to break apart the sections of a rye spike and carry them away would only rattle the maize seetions around in their pouch. Such a wind, however, conld be of scarcely any service to the maize in earrying to a distance its mueh heavier kernels. Hence the husks keep the kernels from being seattered by any wind but one of considerable power. A very strong wind must shake the whole plant vigorously back and forth, and thus will hurl the fruit sections well out of the linsks through the opening above and often high up in the air. The mere force of this throw must carry the kernels a eonsiderable distance, while the strong wind will help them still further on their journey.

The fondness of the coyotes for the fruit of this plant suggests that the liernels are doubtless scattered also to some extent by these animals when they tear off the husks. In this case, of course, the kernels drop rather near the parent plant. There are certain birls, however, whieh may sometimes unwittingly do the plant a good turn by carrying the kernels unharmed for a eonsiderable distance and leaving them in a place favousble for growth. These birls are thieves who have diseovered the secret of the corn's rich treasure, and not content with eating all they can hold earry away many kernels, much as squirrels do with nuts to hide them for future use. As with the squirrel so with the bird, the thief may be killed before he has a chance to enjoy his plunder. Then such of rhe seeds as he had placed in farorable situations would have a chance to grow into new plants. Wolf and bird may be regarded as playing very imperfectly and quite unintentionally the part of farmer. 
It has been observed that half-starved Indians sometimes rob the stores of nuts and eorn which birds or other creatures have colleeter. This has led to the suggestion that the aborigines may have learned the use of maize from the example of these wild animals.

Much the same sort of service that birds and beasts render to maize is performed for wheat and barley by grain-loving ants which live in certain warm parts of the Old World. It is to the remarkable habit which these insects have of storing grain that reference is made in the famous passage from Proverbs (vi. 6-8):

\footnotetext{
"Go to the ant, thou sluggard;

Consider her ways, and be wise :

Which having no chief,

Overseer, or ruler,

Provideth lier meat in the summer

And gathereth her food in the harrest."
}

Throughout Palestine so much importanee has been attached to the finding of these hoards of grain that rules as to ownership have been laid down in the great Hebrew law-book known as the Mishnah. Sir John Lubbock further tells us that "various commentators, ineluding the celebrated Maimonides, have discussed at length the question whether such grain belunged to the owner of the land or might be taken by gleaners, giving the latter the benefit of the doult. They do not appear to consider the rights of the ants."

IIarvesting ants are common in other wam parts of the Old World and in the warmer regions of America. They do not confine their attention to cultivated cereals, but colleet largely from wild grasses. I. 1 Texas what are known as "agricultural ants" make special provision for the growth of a wild grass 
called "ant rice," and regularly harvest and store the grains for winter use. These facts indicate that before wheat and barley eame to be enltivated they may have been helper not a little in the favorable planting of their seeds by the industrious efforts of harvesting ants.

\section{The Infunt Plant and its Food.}

We have seen how every part of a full grown corn plant contributes in some way to the production of offspring well fitted like the parent to lead a prosperous life in the field. TVe have learned, moreover, that wild eorn plants in order to prosper need to adopt precantions and build struetures which become largely unnedeessary as soon as the plant comes to profit by human eare. At the same time such eare, we know, favors in other important ways the production of as fine and as many offspring as possible. Centuries of husbandry have enormously inereased the quantity of seed food provided for each little plant, and also the total yield from a single seed.

Surely the vegetable kingdom has no greater marvel to show than a kernel of eorn. It represents the joint achievement of man and nature working together for untold generations upon this kind of plant to promote the most perfect provision for its offepring.

In order to better appreciate low fully the needs of the infant corn plant are provided for loy the parent, we must examine somewhat more thoronghly than before the contents of the seerl. We have seen that the germ is formed near the base of the seed at one side, while in the remaining space food matcrials are aceumulating. This food, arriving in fluid form, becomes finally changed into a hard, solid mass as the 
nutritive substances take more and more the place of the conveying water. There is, moreover, a loss of the sweetness at first observed, - a loss which becomes perceptible when we compare the taste of a kernel "in the milk" with one fully ripe.

The obvious conclusion from such an experiment is that what arrives as dissolved sugar is somehow changed within the seed into another substance. Chemists using more accurate tests find that in the forming seed, as the sugar disappears, its place is taken by starch. This, as is well known, differs from sugar in having no sweet taste, and in not being soluble in water. A similar change of substance is found to occur in other important constituents of the seed food, making them as insoluble as starch.

An example of the most valuable of these food substances is afforded by what farmer boys call "wheat gum." It is a favorite practice of theirs after harvest to obtain this substance by chewing a small liandful of the ripe wheat kernels. In so doing they perform a sort of rough chemical analysis of the seed food, which is not a little instructive. The "gum," which is their reward for patient chewing of the kernels, is well named, since it lacks none of the qualities essential to a perfect "chewing g"um." That is to say, not only does it retain for some time a pleasant sweet taste, but it is soft and yielding, holds well together, and no amount of ehewing will make it dissolve. When taken from the mouth it is found to be remarkably elastic, stretching and springing back like rubber. It also shows itself as adhesive as glue. In consequence of its glue-like properties it is named "gluten." As we shall see later, it is because wheat 
contains a considerable amount of this tenacious gluten that we are able to make wised bread from wheat flomr. Gluten, moreover, is of the highest nutritive value. In this regard it is equal to the emrd of milk, white of egg, or lean meat. Like them it belongs to the elass of substances known as proteids, which form the chief part of our flesh and blood. In the seed food of the other corn plants proteids also oecur; but these for the most part lack the tenacity and elasticity that make wheat gluten so valuable in bread.

Besides the stareh and proteids contained in corn seeds, there is present a small amount of fatty oil; these are the principal food materials upon which the infant plant must depend for its nutriment. Yet we know that these ean form no part of a watery sap such as a plant needs to nourish it. How, then, can the infant wheat plant profit in any way from these insoluble substances packed in the secd?

Before attempting to answer these questions let us inquire how a similar difficulty is overcome in our own bodies. We know that food cannot nomrish us unless it gets into the blood; and only watery fluids can pass through the walls of the stomach. Whenever we take into the stomach food containing gluten, it comes at once under the influence of a peculiar substance ealled pepsin. This causes insoluble proteids to undergo a curions transformation. However solid or tenacious they may be, mere contact with the pepsin dissolved in the juice of the stomach guartually changes them into readily soluble substanees known as peptones. Passing now easily into the bloot the peptones may be carricil to any part of the body, there to be built into solid flesh. Substances like pepsin, which are believed to have the power to transform 
other substances without being themselves transformed, are called ferments.

In the mouth is formed another ferment, called ptyalin, which has the power of changing stareh into sugar. In the farmer boy's separation of wheat "gum," ptyalin plays a most important part. We may thus explain why the kernels become sweet with

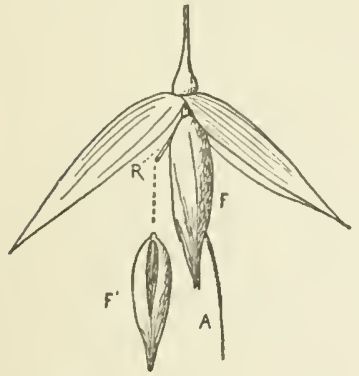

Fic. 18. A spikelet of cultivated oat in fruit. F, the awned inner bract swollen with the ripe grain within; A, awn; F', another ripe "oat" separated from the little rachis $(R)$ aud turned to show its inner face where the edges of the bract inclosing the grain are seen not quite meeting at the centre. About natural size. (Original.)

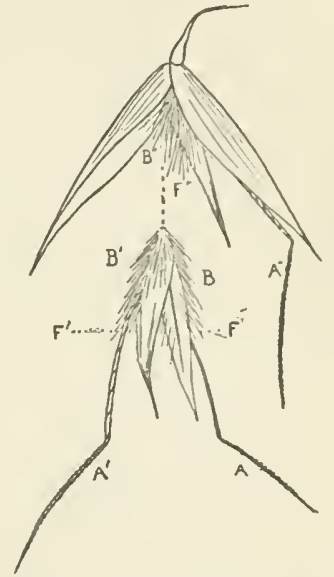

FIG. 19. A spikelet of wild oat in fruit. $F, F^{\prime}$, two fruits separated from the other $\left(\mathrm{F}^{\prime \prime}\right) ; \mathrm{B}, \mathrm{B}^{\prime}, \mathrm{B}^{\prime \prime}$, bristles; $\mathrm{A}, \mathrm{A}^{\prime}, \mathrm{A}^{\prime \prime}$, awns. About natural size. (Original.)

chewing, and why the sweetness finally disappears: As the starcl,, which forms the main bulk of the wheat grain, becomes gradually changed by the ptyalin into sugar, it dissolves in the saliva, is then swallowed, and finally passes into the blood through the wall of the stomach. The sweet taste continues until all the starch mixed with the gluten has been changed into sugar and carried away. 
Ferments having much the same power of changing proteids into peptones and starch into sugar are found in the ripened grains along with the seed food. These ferments are ready to act as soon as the grain is in condition to spront. Let us now see how this process of sprouting or germination takes place.

A ripe kernel of any grain, as we know, is dry and hard, and the germ within is apparently lifeless when it leaves the parent plant. Nor ean it be made to show any signs of life except it have sufficient moisture, air, and warmth. The temperature need not be much above the freezing point of water, or far below what to us feels hot. There should be enough moisture to enable the seed to become well saturated and softened, but not so much water as to prevent free access of air. When placed under these farorable conditions the first clnange to be noticed is a forcible absorption of moisture indicated by a prompt swelling of the whole kemel. So forcibly is the water taken in that the swelling is able to overeome a pressure of more than two hundred pounds to the square inch. Soon after the seed has absorber all the water it can hold, the infant plant begins to show signs of life. It is as if the disturbance of its cradle had at last awakened it from a long sleep, and fancy suggests that the little thing must be hungry. If so, the food is at hand, and now all is in readiness for ehanging the solid materials into liquid nutriment as fatst as the plantlet's needs require. This is accomplished by means of several ferments very much like the two alrealy deseribed. Their liquef ying action begins on that part of the seed food lying nearest to the germ.

If we look now at the germ of maize as shown in Figure 9, we find that the part lying in contact with 
the seed food is in form so different from all the other parts as to suggest its having a special use. This curious shield-shaped part is called the scutellum (sc). On the side in contact with the seed food the scutellum is expanded so as to present as much surface as possible, while its connection with the rest of the germ is at the junction of the young shoot (st) and the young root ( $w$ below). As the plantlet enlarges in germination we find the seed food gradually exhausted, until finally only the empty "hull" is left. Plainly, therefore, the purpose of the scutellum is to absorb the liquefied food coming in contact with its broad surface, and then to conduct it toward that part of the germ whence the nutriment may be most readily distributed to the growing organs above and below. In all the other grains the scntellum is much the same as in maize, only smaller.

The first part of the germ to break through the protective covering is the main root ( $x$, Fig. $10 \mathrm{I}$.). This is soon followed by an upward pointing cylinder (II. b) made up of tiny leaves in tubular form, one within another. At about the same time appear from the side of the little stem the secondary roots (III. $\left.u^{\prime}, w^{\prime \prime}, w^{\prime \prime \prime}\right)$. Such roots rapidly increase in number and importance.

Soon after a root emerges it is found to be nearly covered with delicate hairs, which adhere firmly to any particles of soil with which they may come in contact. Such root-liairs heneeforth perform the work of absorbing water into the plant. The tip of the leafy shoot, at first pale, begins to turn green as soon as it reaches the sunlight. This is a sign that the young plant is making food on its own account; but it is not yet required to depend entirely upon itself. 
There is considerable seed food remaining when this stage is reached. This generous supply enables the plantlet to extend its roots and leaves much farther in a short time than wonld otherwise be possible. When at last the reserve supply is exhansted the infant plant is well able to take eare of itself. It ean thus enter vigorously upon a sumny life in the fields, - a life leading finally to the production of well-developed offspring.

\section{The Advantages of Cereals as Food- Plants.}

From what we have learned of the life of cereal grains it will now be easier for us to understand why they are the most useful of food-plants. A few well known faets will help us to appreciate more fully their importanee to eivilization. The food of savages is obtained principally by hunting and fishing, and by gathering roots, fruits, and seeds of wild plants. The supply of food which may be thus found is so limited in any region that only small and wandering tribes can live in this way. Large and strong nations are possible only where food is marle abundant by domestication of plants and animals. Moreover, since the domestic animals most useful to man live almost exclusively on vegetable food, we see that it is the plants which primarily count. Wild plants, it is true, may largely serve as forage for cattle, sheep, and the like; but forage can seldom be had throughont the year, and the best results in raising anmals are never attained except where forlder is grown for them. Henee increased dependence npon animal food.means generally not less but greater dependence upon cultivated food-plants. 
Of these, as we know, corn plants have always been preferred by the greatest peoples throughout the world. The main reasons for this preference are not far to seek; they relate chiefly to the yield, separation, bulk and keeping of the grain. That is to say, the superiority of cereals depends upon their having important advantages over all other food-plants, not that in any one particular corn plants may not be equaled by others, but that every other food-plant lacks one or more of the great advantages which corn plants combine. These fortunate peculiarities we may now consider.

\section{Yield.}

The foremost advantage of corn plants is the prompt and generous return they make to man for the care he bestows upon them. Even when growing wild or with little care, plants of this sort yield, as we have seen, a considerable amount of food, while intelligent cultivation increases the yield enormonsly. This is well illustrated by the following case, which the ancient writer Pliny tells of as coming up before the magistrates in Rome.

A farmer named Cresinus had astonished his neighbors by reaping much larger crops of grain from a very small farm than they had been able to raise in extensive fields. Noved by envy, they bronght him to trial on a charge of sorcery. "In answer to this charge Cresinus produced his efficient implements of husbandry, his well-fed oxen, and a hale young woman, lis daughter, and pointing to them exclaimed, 'These, Romans, are my instruments of witcheraft, but I cannot here show you my labors, sweats, and anxious cares." Conld the enterprising Cresinus 
have looked into the future and seen the stupendous grain erops produced on our best farms to-day, he would doubtless have found the adrance quite as mysterious as his neighbors found his improvement on what they had done. Nor have we any reason to suppose that our farmers have reached the limit of progress in this direction. On the contrary, it seems to expert students of the question that the farmers of the future are sure to attain an inerease in the yield of eorn plants many times greater than the best results thus far achieved.

The extraordinary yield of cereals is plainly a result of their remarkable fitness for life in the field. This fitness, as we have seen, is shown especially well in their ability to take fullest advantage of every opportunity offered to inerease their facilities for foodmaking. The open field affords just the conditions most needed for this work; that is to say, abundant sunshine, sufficient moisture, and least interferenee from overshadowing plants. The slender, upright form of their green parts permits grain plants to grow well even when erowded rather elose together. Not only ean many stalks then grow up to good advantage from a small area of soil, but the spreading of weeds among them is thereby diseouraged. All this favors rapidity of growth and helps to make the cultivation of eorn plants easy. Rapid development is especially important in northern regions where the growing season is very short. In Lapland barley is harrested about six weeks after planting. while in such warm countries as Spain the farmers reap two erops of barley within the year. 


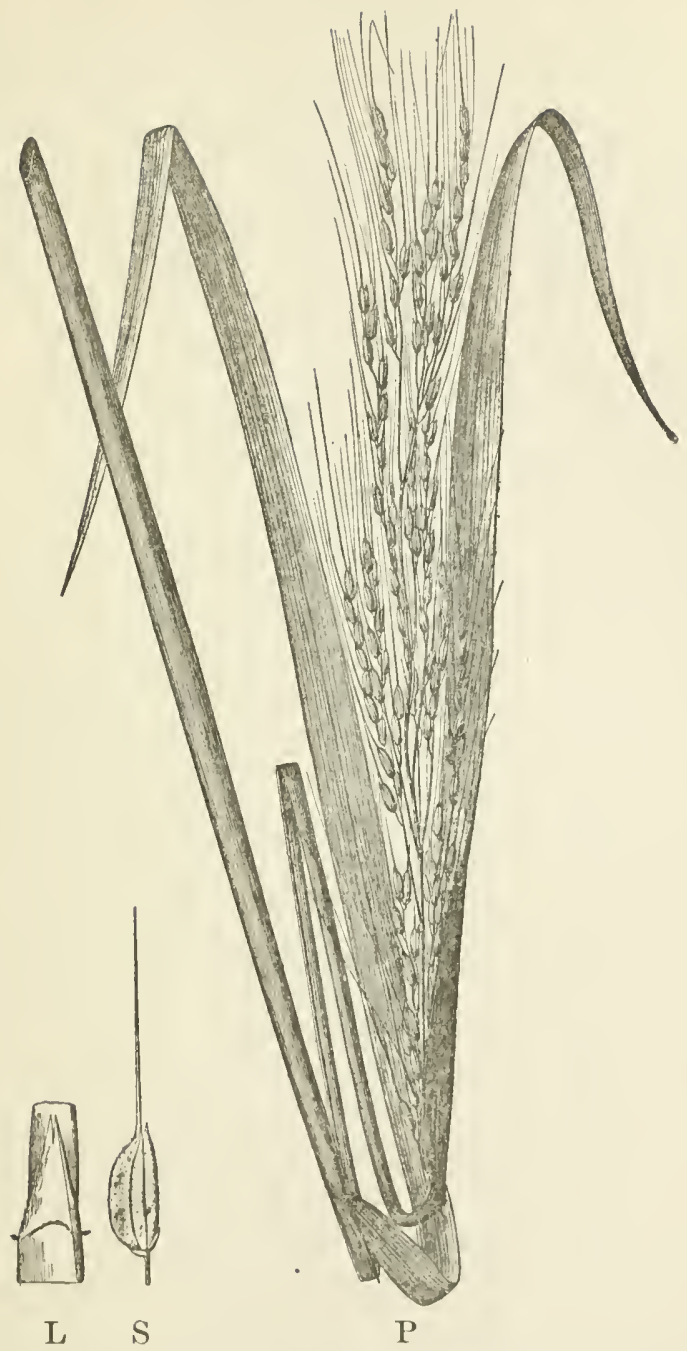

Fig. 20. Rice. P, upper part of a rice plant, reduced in size. $\mathrm{S}$, spikelet. $\mathrm{L}$, ligule. $\mathrm{L}$ and $\mathrm{S}$, natural size. (Martius.) 


\section{Separation.}

Besides being at once exceptionally productive and easy to cultivate throughout a wide range of elimates, corn plants store their nutriment in a form especially easy for man to obtain. Most other food-plants are found to give more trouble than do the cereal grains in one or more of the processes by which the nutritions parts are separated for man's use. Thus, their manner of growth makes the reaping of the grain much less laborious than the harvesting of " rootcrops," which require digging, or of pod plants, such as peas or beans, where hand-pieking is generally required. The arrangement of parts in the ripened ear makes the separation of the liernels a much simpler matter thim the removal of nut meats from their husks and shells. Moreover, on account of the delicacy of the hulls of grains it is prarticularly easy to remove the edible portion of the liernels by milling (i.e. grinding and sifting), and so to render the final preparation of the seed food as simple as possible. In this way, so fully is the most nutritions part of the kernel freed from all indigestible matters that cereal foods when eaten are found to be among the very easiest for the digestive organs to manage.

To the anestion, Why do corn plants yield their kernels so readily to man? the answer plainly is: Becanse at first they conficled their offspring to the wind for transportation. If we ask, Why is the seed food so easy to separate and digest? the answer is equally plain: 'The seed food is stored by the side of the germ. Therefore, simply crushing the grain will free the nutritive part both from the germ and from the hull. Moreover, sinee, in sprouting, the infant 
plant needs to have its food supplied promptly in liquid form, it is neeessary that the nutritious materials should be easy of digestion; and as the digestion of these substances depends on the action of much the same ferments both in the grain and in the human body, we see that what is easy for the one is easy for the other.

\section{Bulk.}

Another important advantage which the grains have for us is that they contain mueh nutriment in little space. In this respect they surpass nearly all the other vegetables used as food. If we compare, for example, the food value of equal weights of wheat grains and potatoes, we find a remarkable differenee between them. Wheat contains over three times as much energy food (starch, ete.), and more than five times as much muscle-forming material (gluten and the like), as we find in potato; while in the potato there is over five times as much water as in the wheat. Thus, to supply our need for muscle-forming materials, one pound of wheat is better than five pounds of potato. Consequently, when food has to be carried from one region to another, grain plainly possesses immense advantages, both in the matter of weight and of bulk. By the use of grains as food, travelers are able to make journeys which otherwise wonld be searcely possible. So also has it been with the great armies of the world in extending their eonquests.

We may account for the superiority of grains in this respect, likewise, by referring again to the needs of the plant. Infant eorn plants in the wild state are, as we have seen, extensive travelers, while such buried off-shoots as potatoes we know to be stay-at-homes, 
sprouting where they were formed. We should expect, therefore, that potatoes would be large and full of water, since weight and bulk have no disadvantages for them. For kernels of grain, on the contrary, lightness is plainly essential so long as they depend on the wind to car'ry them. Hence we find the infant corn plant provided for its journey with a ration eomposed of the most nutritions food-stuffs, in a form as compact as possible.

\section{Tieeping.}

Finally, it should be noticed that the extreme dryness of the kernels, taken in comnection with the faet that only a very small amount of oil is present in the seed food, gives another advantage to the offspring of corn plants and increases their value to mankind. Seed food which is moist or is rich in oil must be used within a comparatively short time, or it will be found to have tumerl rancid or to have become otherwise spoiled. The oily keruels of virious nuts, for example, have this drawback. Grains, on the eontrary, if properly stored, may be kept unchanged for very many years. Thus, hy wise foresight, man is enabled to make sure of his daily bread even through years of famine. That this advantage was very early appreciated among ancient peoples is well shown by the story of Joseph in Egypt (Genesis xli.).

In our own day the storage of grain in prosperous regious during seasons of plenty has proved vastly important as a safeguard of eivilization. Faminestricken peoples in various parts of the Old World have often owed their lives to the breadstuffs sent from American granaries. With regard to the eorn plants themselves, even when will, it is easy to see 
how the good keeping qualities of their seed food would sometimes be of benefit. After the kernels have been carried away by the wind it cannot always happen that they will come at onee under the neeessary conditions for germination. If such kernels ean safely wait a long while before sprouting, their chance of final success is plainly increased. In this respect, therefore, the seeds of corn plants have an advantage over many others which must die within a few months if they fail to germinate.

\section{Summary.}

The chief advantages of eereals as food-plants have now been mentioned. Without exception we have found that the features which make corn plants especially useful to man are of benefit to the plants themselves as dwellers in the field. We may conclude, therefore, that their great usefulness to us is mainly due to their wonderful fitness for field life and their unstinted provision for the welfare of their offspring. It is chiefly beeause they provide so well for their young that man has eome to eare for them and multiply their kind. Man takes for his share of their produce the surplus of seeds which the wind once wasted, but by the rest he makes their life more and more abundant. Each kind, at first growing only within comparatively narrow bounds, now under man's eare flourishes far and wide. 'To corn plants have been given the greater part of the richest fields of the earth.

\section{Wheat, the King of Cereals.}

Throughout the civilized world, wherever wheat will grow or where the people are not too poor to buy it, 
this grain holds the foremost plaee. It has always yielded "the staff of life" to the greatest and most powerful nations since the beginning of history.

Wheat has been so long and so widely eultivated that the question of where it first grew wild is one very diffieult to answer with entire certainty. It seems highly probable, however, that the native home of wheat was in the region of Mesopotamia. (See map, p. 103.) Botanists believe also that wheat was first cultivated in the fertile valley of the Tigris and Euphrates. As a centre from which to spread most widely and rapidly, this region would surely have been the most fortunate possible, sinee it lies in that part of Asia which is within easiest reaeh of both Afriea and Europe. Henee from no other loeality could this invaluable food-plant have been carried so readily into the other parts of the Old World where civilization might best advanee. There seems good reason to believe that eivilization first arose in the home of wheat, and that the highest eivilizations have always depended in their eonquests mpon the king of cereals.

We know that in Palestine and in Egypt wheat was eultivated long before the dawn of history, and that in very early times its eulture had extended eastward to Persia, India, and China, westward to Greeee and Rome, and northward or northwestward into central Europe. Wheat was first brought to the New World soon after the diseovery of Ameriea by Columbus. To-day the United States produces more wheat than any other nation.

This grain holds the highest place among corn plants beeause only from wheat flour ean raised white bread be made. The whiteness of wheat products 
has long been recognized as their most characteristic attraction. Indecd "wheat" and "white" come from

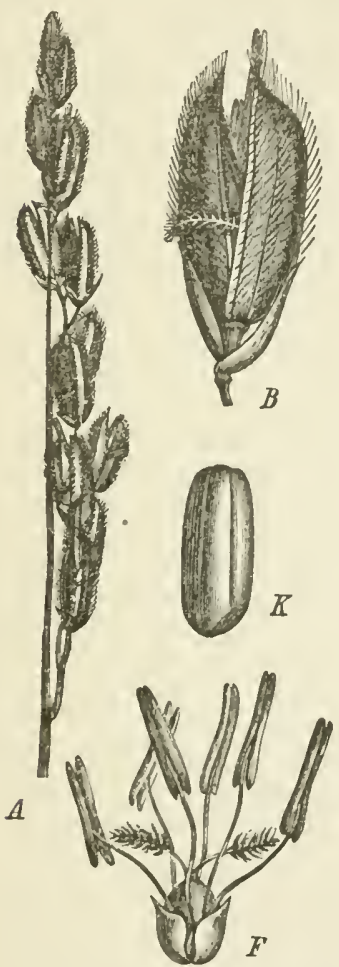

Fı. 21. Rice. $A$, part of inflorescence. $B$, a spikelet in flower. $F$, a flower showing six stamens, a pistil with ovary, two styles and stigmas, and a pair of lodicules at the base. $K$, a kernel. (Ӓeеs.)
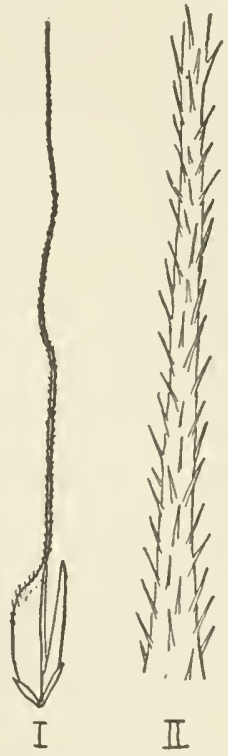

Fro. 22. Rice. I, a spikelet of a bearded variety, showing the long awn developed from the tip of an inner bract. Natural size.

1I, a part of the awn, enlarged, to show the upward pointing barbs. (Original.)

the same word in the ancient Anglo-Saxon language. It still remains true with us that white bread is always wheat bread.

The raising of bread, as already stated, depends 
upon the presence of gluten. As raised bread is most commonly made the flour is mixed with a little water and yeast to form a stiff dough, which then is vigorously kneaded so that the yeast may be well distributed throughout the mass. This accomplished, the dough is put in a warm place to "rise." The conditions are now favorable for the yeast to begin its work. What this work is may be understood from the fact that yeast contains a ferment, which, like some of those already mentioned, acts on starch. Yet while these, as will be remembered, simply turn starch into sugar, the yeast ferment has the power to make, from starch, alcohol and an odorless gas known as carbon dioxide. Each particle of yeast, made warm and moist and surrounded by starch, becomes thus a tiny gas factory. If there were nothing to prevent, the gas would, of course, escape. But in the wheat dough the gas is held in little carities by the gluten. As the gluten is elastic these cavities become larger and larger with the pressure of the gas within. It is this enlargement of innumerable small cavities throughout the dough which makes it "rise" into a light spongy mass ready for baking.

The heat of the oven stops further action of the yeast, enlarges somewhat the cavities in the dongh by expanding the gas, hardens the gluten so that the cavities cannot shrink, and then drives off the greater part of the moisture, alcohol and carbon dioxide. At last the crust comes to a perfect brown, indicating that the best flavor of the wheat has been developed. The final result is a loaf of wheat bread, the highest type of human food.

The peculiarities of wheat gluten also make possible such valuable foods as macaroni, which consists 
very largely of this substance. The same is true in general also of crackers or biscuits, especially the tough, long-keeping sort known as ship-biscuit or hard-tack, which forms the chief vegetable food of erews at sea. In general it may be said that the innumerable articles of human food which consist wholly or in part of wheat owe their special excellence to the peculiar properties of the gluten present.

The starch which forms, as we know, the main part of the wheat kernel is likewise of great value, not only in the foods above mentioned, but also by itself when separated as a pure product. Wheat starch is extensively used as a material for paste or sizing in various manufactures.

Just as the inner part of the kernel is invaluable for human food, so the outer part or "bran," which includes bits of hull and adhering particles of seed food, is one of the very best feeding stuffs for domestic animals. The straw, both green and ripe, is also widely used for the same purpose.

On the immense wheat farms of the far West, the straw is used in curious ways. At harvest it supplies the fuel for great steam threshing-machines as they work in the ficlds. One part of the wheat plant is thus made to help prepare another part for market. In some regions the straw is used for building barns in which to store the grain. This is accomplished by making solid bales or blocks of the material under great pressure and piling them like stones to form a thick, substantial wall. A roof, perhaps thatched with straw, completes the structure.

Not the least important use of wheat straw is as material for the finest kinds of straw hats and bonnets. In Italy an especially slender variety of wheat 
is grown for the purpose by sowing very thiclily in poor soii. From straw thus raised the famous Florentine or Leghorn hats are manufactured. Stonter kinds of wheat afford material for hats made of coarser braids.

Thus we see that every part of a wheat plant is put to important and remarkably varied uses. But few plants besides wheat can be said to furnish food, fuel, shelter, and clothing.

\section{Oats, the Grain of Hardiness.}

It is told of an Englishman, who was fond of poking fun at the Scotch, that one day he saw a Highlander with a bag of oats, and remarked, "There's what feeds horses in England and in Scotland feeds men." "True enough," replied the other, "and that's why ye 've such fine horses and we've such fine men!" The Scotchman's retort showed no less wisdom than wit, for oats have long been the favorite food of the hardiest peoples of northern Europe, and this grain is generally recognized as the most strengthening fodtler for hard-working animals.

Oatmeal is found to contain more proteid or muscleforming substance than the average wheat flour. The proteid of oats is inferior to wheat gluten only in being somewhat less digestible. In fatty material oats are the richest of all the grains.

For northern peoples this grain has the advantage over wheat that it will grow at its best in eold elimates. But it does not ripen its kernels well in regions as far south as the Mediterranean sea, where wheat seems thoroughly at home.

From these and other facts botanists conclude that the original home of oats was most probably in cen- 


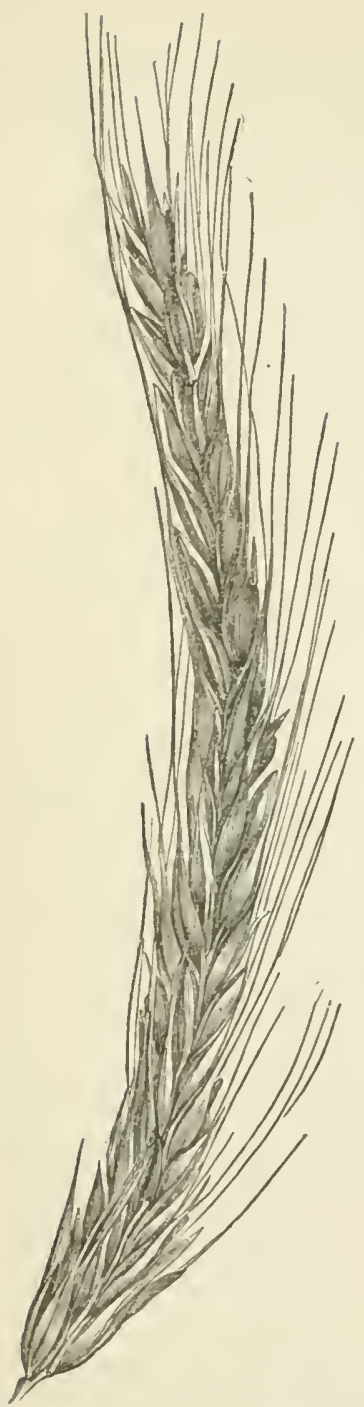

F1. 23. Rye, inflorescence. (Mull-Guyot.)

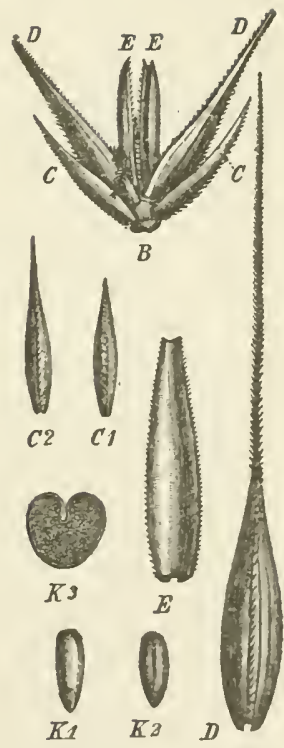

Fro. 24. Rye. $B$, a single spikelet showing its two flowers. $C^{1}, C^{2}$, outer bracts. $D$, inner bract with awn at tip. $E$, inmer bract without awn. $K^{-1}$, kernel viewed from the germ side. $\boldsymbol{K}^{2}$, the same viewed from the greored side. $K^{\prime 3}$, the same enlarged aud cut across. (Nees.) 
tral and eastern Europe, extending perhaps into western Asia. (See map, p. 103.) So far as may be judged from ancient remains the cultivation of this grain first began in middle and northern Europe, long after the introduction of wheat but before civilization was established. It is not mentioned in the Bible, and seems to have been entirely unknown in ancient Assyria and Egypt. To-day the cultivation of oats has extended eastward to China and westward to the L'nited States and Canada, where large crops are now raiserl. In Scotland and Ieeland oats yield the chief regetable food.

Since good raised bread cannot be made from this grain, it is mainly used in the form of meal cooked either as a porridge or baked into flat cakes. Much use is also made of the kernels, whole or crushed, freed from the hulls and cooked like rice. Such hulled kernels are known as "groats" among' the Scotcl, who depend on them very largely for food. It is in reference to this article of dict, as eharacteristic of these hardy people, that the quaint name, "Joln o' Groat's House," has been given to the extreme northeastern point of Scotland. The "oatmeal" so widely used as a breakfast food in America is more truly "groats," or " grits," than meal.

'The straw of oats has important uses. As a foclder and bedding for horses and cattle it is generally preferred by farmers to the straw of either wheat, bar'iey, or rye. Mamufacturers of coarse paper and pasteboard use considerable quantities of oat straw. It is also one of the most useful sorts for packing and for filling mattresses.

In many localities oats are grown to be eut green as hay. In warm regions, such as om Sonthem States, 
where the ordinary hay grasses do not flourish, oats are successfully cultivated for this purpose, because the stalks and leaves grow luxuriantly, although the kernels are poor.

The worst enemies of the oat are heat and drought. Its hanging spikelets shed the rain, and wind and cold ean seareely harm it. It is the grain of hardiness; for not only is it the hardiest of corn plants, but it is the one which forms the main support of hardy northern peoples.

\section{Rye, the Grain of Poverty.}

Rye will grow and produce a fairly good crop where the soil is too poor or the climate too hot or too dry for any other cereal to thrive. Such conditions are found over the greater part of northern Europe and Asia. In these vast regions, therefore, rye is the staple bread-stuff, and forms the chief food of the peasant classes. Indeed, it would seem that a large part of northern Europe and Asia could scarcely have become populated as it is to-day except for the possibility of growing rye on poor soil.

The original wild form of this grain is believed by botanists to have been native to monntainous or mostly dry localities, in the sonth of Europe and extending perhaps to central Asia. The native home of rye would therefore seem to be in a region between the home of oats on the north and that of wheat on the south. (See map, p. 103.)

There is no reason to suppose that the great peoples of antiquity were aequainted with rye. The nime occurs, it is true, in our Anthorized Version of the Old Testament (Exodus ix. 32, and Isaiah xxviii. 25), but, as shown by the Revised Version, the Hehrew 
word at first translated " rie" is now known to mean "spelt," which is a peculiar kind of wheat.

The eultivation of rye probably first began in southern Russia and Siberia, whence it extended to other parts of Europe during the Christian era. From Europe it was brought to America by the early colonists. Among the peasantry of Germany and of Russia, a dark-eolored bread, tough and coarse, is made of rye meal or bran. This forms their most important food. In Sweden rye grows especially well, and bread made from the flour is the favorite food of all classes. Rye is less nutritious than wheat or oats, but generally contains more proteid than either barley, rice, or maize.

During the early history of our country rye was much used because of its ready growth on soil not well fitted for other grains. The meal, mixed with that of Indian corn, made a "brown bread" similar to that still widely enjoyed in New England. Another use for which rye largely served was the making of whiskey.

While rye has continued to be raised in considerable quantities for the making of whiskey, its use for food in this country has come to be very small in comparison with that of whent, oats, or maize. On worn-out or thin soils it is grown somewhat extensively as a green-forage crop. When ripe the straw becomes the poorest for fodder of any eereal straw, because it is then the most harsh and tough. These very qualities, however, combined with unusual length in the stalks, make rye straw the best for such purposes as packing, and bedding for horses and eattle, and as material for cheap straw hats, straw paper, and straw pastehoard. Such large quantities are used in these ways, and rye 
straw is so much preferred to any other, that many of our farmers, especially in the East, raise rye more for the straw than for the grain.

\section{Barley, the Brewer's Graln.}

Our study of wheat, oats, and rye has shown them to be examples of the general rule, that the characteristic food of a people is largely determined by the climate and soil of the region in which they live. The same rule applies to alcoholic beverages. Thus in southern Europe and other regions where the winegrape grows well, wine is the common drink; and brandy, which is distilled from wine, is the form of spirit most in use. In such regions as northern Europe, however, which are too cool or too dry for wine-growing, the popular alcoholic drinks are obtained from grains. That is to say, whiskey and gin, which are distilled mostly from rye or maize, largely take the place of brandy; while beer, ale, and the like, which are made principally from barley, serve much the same purpose as wines. These facts add interest to the following statement of the ancient Grecian historian Herodotus regarding the Egyptians of his day: "They use," he says, "wine made of barley, for they lave no [grape] vines in that country." What Herodotus meant by "wine made of barley" was doubtless a sort of beer similar to what is brewed from barley to-day. At the present time, not only is beer made principally from barley, but the prineipal purpose for which barley is raised is the brewing of beer.

The process of brewing is essentially as follows: First, kernels of barley are soalked in water for a ${ }^{1}$ Herodotus, Book II., chapter 77. 
while and then spread out to spreut. In the process of germination, as we have seen, the stareh of the seed food is turned into sugar, which is then absorbed by the germ. Hence, up to a certain point in the process, the sugar increases in amount, and after that, becomes less and less as the plantlet grows. Just as soon as the brewer finds that the largest possible amount of sugar is present, the sprouting is stopped by heating the grains sufficiently to kill them. Grains thus sprouted and killed at the proper time are lnown as malt. Such was "the malt that lay in the house that Jack built." Malting is the first step in the making of beer. The second step is grinding the malt and soaking it in water to dissolve out the sugar. To the sweet liquid thus obtained yeast is added to bring about fermentation. As in the "raising" of bread, the sugar is transformed into alcohol and carbon dioxide gas. When the fermentation goes on in a closed vessel, as a cask or a bottle, the gas is retained in the liquid and when the beer is drawn forms bubbles of foam.

Just as sugar is turned to alcohol by yeast, so, throngh the action of another ferment, alcohol is turned to the acid of vinegar unless means are taken to prevent it. Beer is now generally kept from souring by the addition of hops, the flowers of which eontain a bitter substance that does not interfere with the working of the yeast, but retards the aetion of the aeid ferment.

Other malt liquors, such as ale and porter, are made from barley in much the same way as above deseribed. When other grins are malted the process is the same as with barley. Spirituons liquor's, such as whiskey and gin, are marle by distilling a sort of 


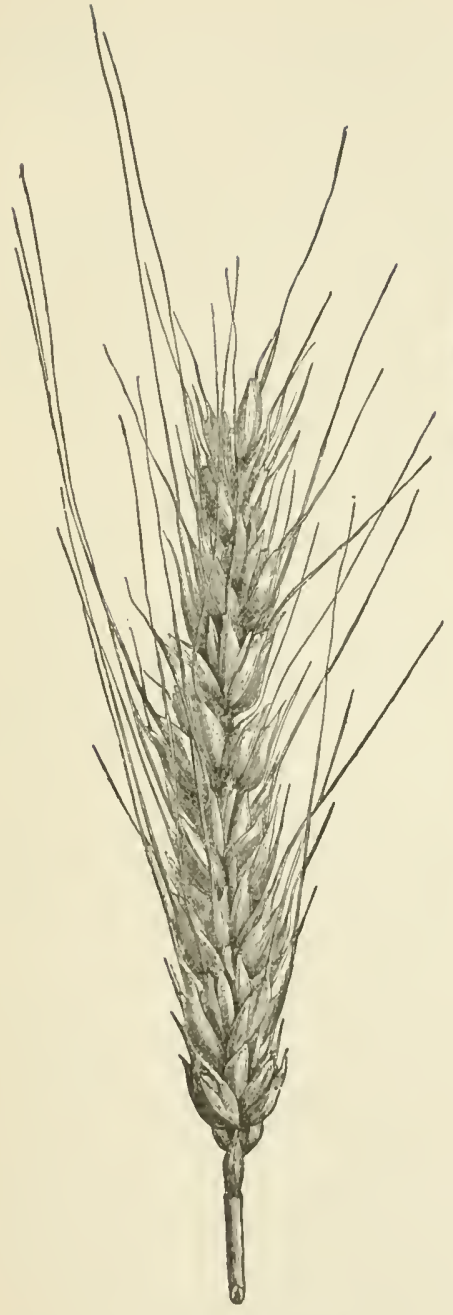

Fig. 25. Common bearded wheat, inflorescence. (Hackel.)

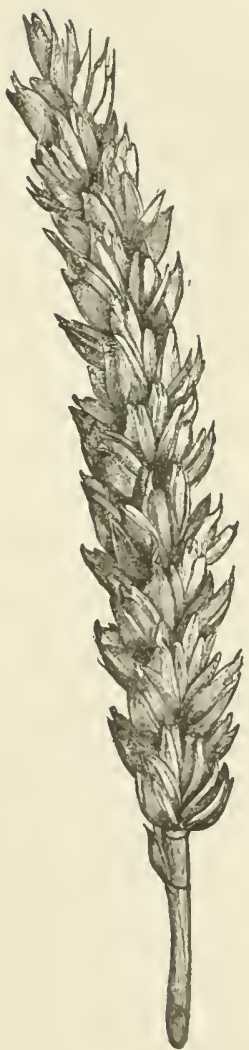

Fra. 26. Club wheat, inflorescence. (Hackel.) 
beer. That is to say, from a weak alcoholic liquid the fermented extract of some malted grain - a strong liquor is prodnced by a peculiar process of concentration.

Brewers prefer barley to any of the other grains for malting, becanse of its exceptionally ready germination. Its very general use for beer-making is favored also by the fact that it thrives over a wider range of elimate than any other corn plant. It grows well even farther north than oats, and at the same time will flourish in sub-tropieal soil.

The native home of barley is believed to be in sonthwestern Asia. (See map, p. 103.) From the very earliest times it has been extensively grown by the great peoples of antiquity who dwelt about the Mediterranean sea. Recorls of its use in ancient Egypt, Assyria, Palestine, and Greece, indicate that barley was cultivated as early as if not earlier than wheat.

Until modern times its principal use has been for food, although, as we have seen, it has long been used also for beer. $\Lambda$ s a bread-stuff barley has always ranked lower than wheat. It has served chiefly as a food for the poorer elasses who could not afford much wheat. The aneients used to feed their athletes on barley bread, in the belief that it was an especially strengthening food. From their use of this fool the Roman gladiators were ealled hordeurii, or "barley. boys," as we may freely translate it, mueh as the name "beef-eaters" is now applied in England to the yenmen of the royal guard. In the great armies of antiquity barley was largely used as food for both man and beast. Nebuehathezzar's horses and Solomon's dromedaries were doubtless fed on barley. 
At the present day, in warm regions where oats do not thrive, barley is used considerably as a fodder. As a human food, however, it is now used only to a comparatively small extent throughout the world. With us it is eaten almost entirely as "pearl-barley." This consists of the kernels deprived of their outer coverings and rounded. It appears in modern cookery chiefly as an addition to broths or soups. The mutritive value of barley is usually less than that of either wheat, oats, or rye. From being the grain most used as food by the ancients, barley has now come to be eaten less than any other grain. Were it not for the extensive use made of this grain by brewers, only a comparatively insignificant amount would now be raised.

X. Rice, the Corn of the East.

Rice gives food to more people than any other corn plant. It is, however, the least nutritious of cereals, and as commonly cultivated would seem to require more labor and care than most of the other grains. Nevertheless, rice forms the chief food, and of the poorer classes almost the only food, throughout large parts of India, ${ }^{1}$ China, Japan, and the East Indies. It is used also extensively in other regions of moist climate within or near the tropics. The main reason for its being the food of so large a part of the human race is doubtless to be sought in the fact that about half the population of the world live crowded together in the Eastern countries above named. There, owing to the heat and abundant moist-

${ }^{1}$ Indian millet takes the place of rice in the dry portions of India, and the total amount raised throughout the country is greater. 
ure in the lowlands, rice yields more than any other cereal would do under the circumstances. Its native home (see map, p. 103) is in southeastern Asia. As we have already seen, rice has been cultivated by the people of the East for over forty centuries.

Growing rice affords some of the most attractive features of Eastern landscapes. The Rev. Francis Tiffany, writing of Japan, reeords as follows his impression of rice-fields :

"Not personally addicted to rice as an article of diet, - unless, perhaps, as a mere vehicle for the piquant stimulus of curry, - I was soon foreed to admit that the cultivation of this cereal for purely asthetic ends would prove an enhancement of the charms of the Garden of Eden. At this late September season of the year, the rice-lands stretch out in the sunshine a sea of gold. Since rice declines to grow except in water, and water declines to stand still except on a perfect level, the immense area of alluvial deposit in which the plant roots wears the look of a lake of luxuriant, sunlit regetation. Encireling in graceful eurves this vast burnished expanse - now jutting out into it in promontories and now retreating to leave space for lovely bays - are hills densely wooded, completing the picture with ravishing contrasts of form and color.

"Curiously enough, each charming little valley, with its brook winding down between the densely wooded hills to the shining level of the plain, now delights the eye with the exact transeript of a series of beautiful cascades of golden rice. As, in the gardens of Versailles, streams of water are made to run down great flights of broarl stone steps, breaking into a gentle fill at eaeh suceessive step, so liere the sime 
effect is wrought by utilizing the water of the descending brooks for successive terraces of rice. So vivid the impression of life and motion, that literally it seems as though the beautiful plant itself had taken to the mobile ways of the element in which it grows. When one pictures the scene of an infinite variety of these lovely little valleys pouring their brooks of gold throngh luxuriantly wooded defiles into a sea of gold below, he will have presented to the mind the sight that makes one of Japan's most characteristic beauties." 1

In our country the cultivation of rice is restricted mostly to the low-lying parts of the South Atlantic and Gulf States. The total yield for the United States is less than that of any of the other cereals we have been considering.

\section{Maize, the Conn of the West.}

Indian corn forms by far the largest cereal crop of the Western Hemisphere. In the United States the amount raised is greater than the sum of all our other grain erops, and doubtless considerably exceeds the total maize produet of the rest of the world.

The place of maize in the Western Hemisphere is similar to that of rice in the far East. As the native home of rice was in tropical Asia so that of maize was in tropical America. (See map, p. 103.) Although in their original wild state both were thus tropical grasses, there was this important difference, that, whereas rice grew mainly in the wet lowlands, ${ }^{2}$ maize

1 This Goodly Frame the Earth, p. 27.

${ }^{2} \mathrm{U}$ pland rice, a variety requiring abont the same amount of moisture as maize, is eultivated to a limited extent on rather dry soils at considerable altitudes. It is muel less productive 
was a highland plant, and this fact has made possible a much greatei range of cultivation for the corn of the West. That this would naturally be the case is plain when we remember that at high elevations in the tropies the climate is like that of lower altitudes in temperate lands, while the climate of tropical lowlands can be matehed only within or near the tropical zone. "Maize or "Indian eor"," says John Fiske," "has played a most important part in the history of the New World, as regards both the red men and the white men. It could be planted without elearing or ploughing the soil. It was only necessary to girdle the trees with a stone hatchet, so as to destroy their leaves and let in the sunshine. A few scratches and digs were made in the ground with a stone digger, and the seed once dropped in took eare of itself. The ears could hang for weeks after ripening, and could be picked off without meddling with the stalk; there was no need of threshing and winnowing. None of the Old World cereals ean be cultivated without much more industry and intelligence. At the same time, when Indian corn is sown in tilled land it yields with little labor more than twiee as much food per acre as any other kind of grain. This was of inealeulable advantage to the English settlers in New England, who would have found it much harder to gain a secure foothold upon the soil if they had had to begin by preparing it for wheat and rye without the aid of the beautiful and beneficent American plant. The Inclians of the Atlantic coast of North America for the most

than lowland rice, however, and the amount raised throughout the world is comparatively insiguficant. The statements above apply only to lowland riee.

1 The Discovery of America, vol. i. p. 27. 
part lived in stockaded villages, and enltivated their corn along with beans, pumpkins, squashes, and tobacco; but their cultivation was of the rudest sort, and population was too sparse for much progress toward civilization. But Indian corn, when sown in carefully tilled and irrigated land, had much to do with the denser population, the increasing organization of labor, and the higher development in the arts, which characterized the confederacies of Mexico and Central America and all the pueblo Indians of the southwest."

The religions ceremonies already referred to, in which the ancient Americans showed their appreciation of the value of maize, indieate plainly that these people must have been acquainted

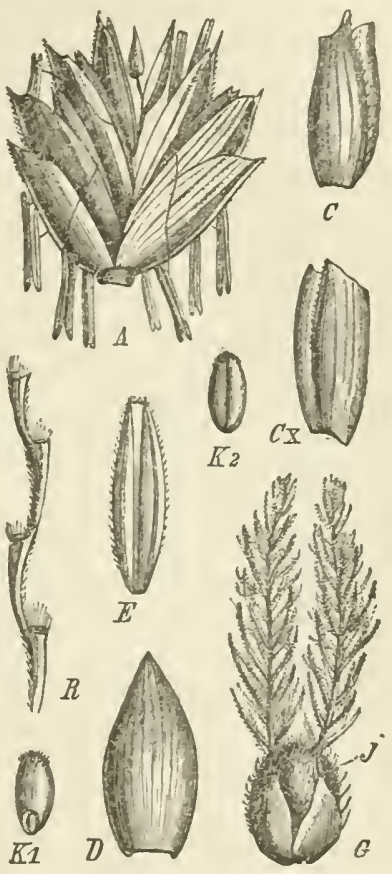

Fro. 27. Wheat. $A$, spikelet. $C, C x$, outer bract, back and sile views. $D, E$, inner bracts. $G$, pistil with pair of lodicules at base ; $J$, ovary. $K^{* 1}, K^{2}{ }^{2}$, kernel, front and back views. $I$, rachis. (Ilackel.) with the plant for many centuries before the coming of Columbus. Other facts go to show that long before his arrival the culture of maize had spread from Mexico as a centre into tho temperate regions of North anr South America. ${ }^{1}$

- The proofs of this view are given at length in Dr. John 
When Columbus landed in the West Indies the natives gave him a sort of bread made from a grain which they called makiz. In his letters to Spain he spoke of the Indian corn under this name, and from it has come our English word "maize."

Although Columbus and his followers on their return home took seeds of the Indian corn with them, its value seems to have been appreciated very slowly by Europeans outside of Spain and Portugal. Until the present century it was regarded by them rather as a curiosity than as a valuable food-plant. At the same time its use spread remarkably in Africa and Asia, extending even to China. "It is found at the present time in the East Indies among savage people, who have no history or tradition of how or when it was brought there. It appears to have been adopted by the barbarous nations of the Old World more rapidly than by the more enlightened countries of Europe. Probably this is due to the fact that it was peculiarly well adapted to the agriculture of a semibarbarous people." 1 It is now cultivated very extensively in the warmer parts of the Old World, especially in Asia.

The early settlers in Ameriea learned from the natives, not only their simple method of raising the corn, but also some of the best ways of using it. In Mexico the Spaniards found the natives making a sort of bread after the following primitive fashion: 'They first soaked the whole kernels in hot water, with

W. Harshberger's Maize: A Botanical and Economic Study, 1893, which contains also much other valuable information regarding this plant.

1 Wm. IH. Brewer, Cereal Production, Tenth Census of the United States, iii. 475. 
a little lime to soften the hulls, until the whole was tender; then the grains were cleaned and erushed, and finally made into a paste. This was baked by spreading a thin layer over heated stones. Such thin cakes, to which the Spaniards gave the name "tortillas," soon came to form the chief bread of the invaders, and to this day throughout Mexico it is a favorite food of all classes.

A somewhat similar food is prepared by the Indians of our southeastern States. It is thus clescribed by one who has lived among them: "The blue variety [of corn] is preferred for bread, and is sorted from the rest with much care. . . . The corn, after being reduced to meal in a stone mortar, has a peculiar bluish-white appearance. In converting it into bread, it is mixed into a thin batter, and a brisk fire is made to heat a slab of iron or stone, or a flat earthenware plate; ... when [the slab is] sufficiently heated the women press the fingers of the right hand togrether, dip them in the batter, draw them out thickly eovered with the mixture, ... [ [and pass] the hand equally over the heated baker, leaving a thin coating, which quickly curls up, a sign that it is cooked on that side; it is then taken off, another dip made with the fingers, and the baker is besmeared again; then the upper side of the first cake is laid on top of the new dip ; when the second one is ready to turn, the first one is alrearly cooked, and the second is put through the same process as the first; and so on until a number of these large thin sheets of wafer-like bread is aceumulated. They are rolled up together and form what is ealled by the Moqui Indians 'guagava.' It looks like blue wrapping paper, but somewhat coarser and has a polished surface. . . A At first it seems dry 
in the mouth, but it soon softens, is quite sweet, and is easily masticated." 1 Other Indians make the meal into a flat cake which they cook in hot ashes. From such primitive examples of cookery were doubtless derived the "ash-cake," "hoe-cake," and " corn-pone," so widely relished throughout our Southern States.

The early settlers in New England adopted several of the Indian methods of preparing maize, and in some cases kept the native name for the dishes with but little ehange. Thus the mixture of green corn with beans, which is now known as "suceotash," was called by the Indians msickquatash. Similarly our "hominy," which is a sort of maize "groats," was known to the Indians as authminea. Furthermore, we learn from Roger Williams, ${ }^{2}$ the founder of Rhode Island, that the native nasaump, "a kind of meal pottage, unpartch'd," beeame the "samp" of the English colonists. "Samp," he says, " is the Inclim corne, beaten and boiled, and eaten hot or cold with milke or butter, which are mercies beyond the native's plaine water, and is a dish exeeeding wholesome for English bodies."

Parehing or toasting the corn he further tells us was a method of preparation much practiced by the Indians. Regarding the parched meal, he writes: " [It] is a readie very wholesome food which they eat with a little water, lot ol cold; I have travelled with neere 200. of them at onee, neere 100 . miles through the woods, every man carrying a little Basket of this at his back, and sometimes in a hollow girdle about his middle, sufficient for a man three or four daies;

1 Food Produets of the North American Indians, Report U.S. Department of Agriculture, 1870, p. 420.

${ }^{2}$ A Key to the Languaye of America, 1613, p. 12. 


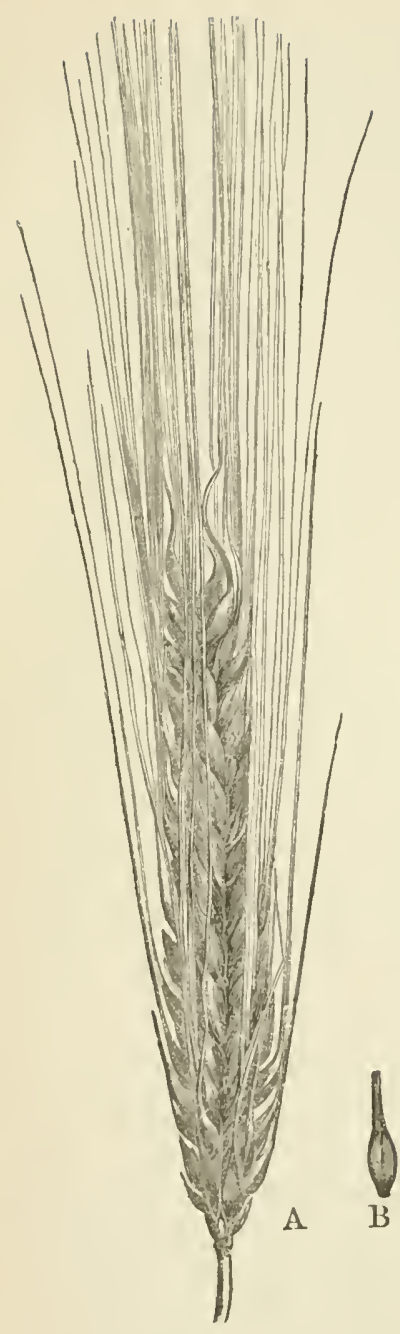

Fig. 28. Common barley. A, inflorescence. $\mathrm{B}$, base of a siugle spikelet. (Hackel.)

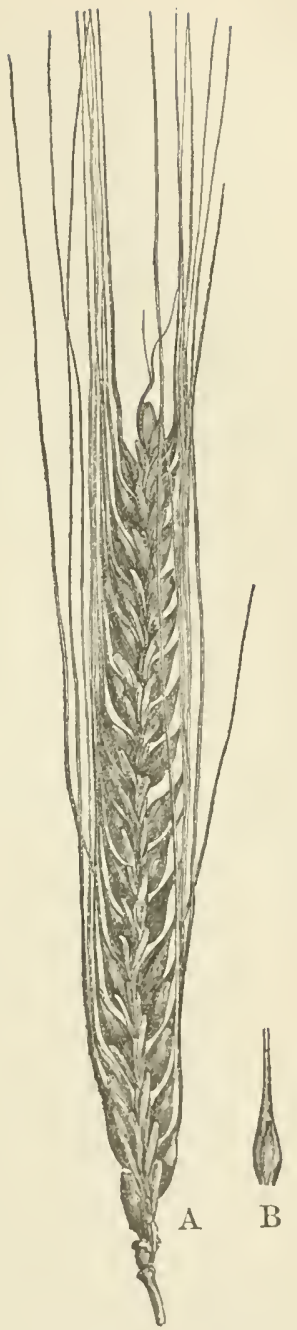

Fig. 29. Two-rowed barley. A, inflorescence. $\mathrm{B}$, base of a single spikelet. (Hackel.) 
with this ready provision, and their Bow and Arrowes, are they ready for $\mathrm{W}^{\mathrm{a}} \mathrm{ar}$, and travell at an houres warning. With a spoonfull of this meale and a spoonfull of water from the Brooke, have I made many a good dinner and supper." 1

Dr. Benjamin Franklin tells us of the following curious method of parehing corn praeticed in his day by the farmer's, and evidently borrowed from the Indians. "An iron pot is filled with sand, and set on the fire till the sand is very hot. Two or three pounds of the grain are then thrown in and well mixed with sand by stirring. Each grain bursts and throws out a white substance of twice its bigness. The sand is separated by a wire sieve, and returned into the pot to be again heated, and repeat the operation with fresh grain. That whieh is parehed is pounded to a powder in mortars. This being sifted will keep long for use. A Indian will travel far and subsist long on a small bag of it, taking only six or eight ounces of it per day mixed with water." 2

In this singular preparation, the reader will donbtless reeognize the original of our modern "pop-eorn," - a foor as digestible as it is delieions, and one well wortlyy of wider use to-rlay.

Of the many other uses which maize has come to have in morlern times, only brief referenee may here be made to a few of the most important. Its value to man as furnishing a rich variety of food-produets for himself is seareely greater than its service in providing fodder for his domestic animals. The ripened grain affords a food which is exceptionally fattening, while the "stover," or those parts of the plant left

1 The same, p. 10.

2 Franklin's Works, 1818, vol. ii. p. 277. 
after removal of the ears, is found to be as nutritious as the best hay. Farmers plant maize also very largely for green fodder. Either this is fed fresh or it is kept moist by packing closely in air-tiglit structures called "silos," where it ferments somewhat and becomes what is known as "ensilage."

The pith of the mature stallss yields a material whi ch from its property of swelling rapidly when wet has an important use in the construction of war vessels. A thick layer of this material firmly packed behind the armor of the liull at and near the water line prevents leakage in case a shot penetrates the steel covering. Several of the
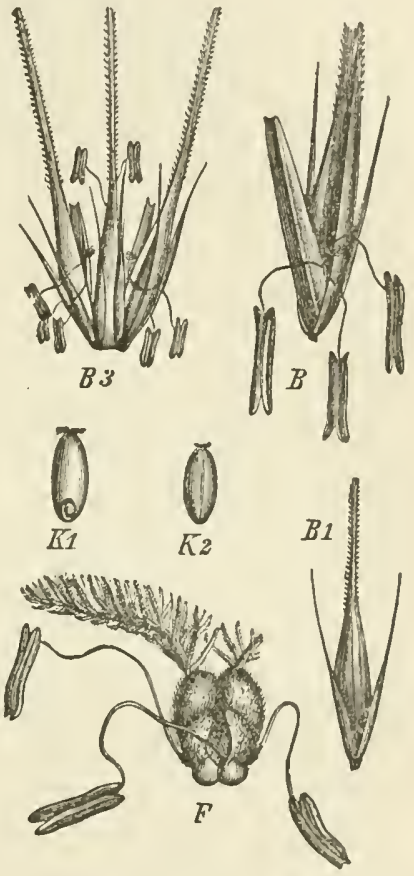

Fig. 30. Six-rowed barley. $B^{3}$, a group of three spikelets from one node of the rachis. $B$, $B^{1}$, single spikelets. $F$, a flower (one stigma partly removed). $K^{1}, K^{2}$, back and front views of keruel. (Nees.) battleships of the United States Navy are thus protected.

The stalks, leaves, and husks have been found to yield excellent material for paper, and also fibres which can be woven into fabrics. The husks have, moreover, considerable value as packing material, as 
stuffing for mattresses, as material for coarse matting, and other minor uses.

In the Western States, where coal and wood are especially high, ears of corn, or the cobs after shelling, form an economical fuel. One hundred bushels of corn in the ear are about equal in fuel value to at cord of hard wood ; three tons of corn-cobs equal about one ton of hard coal. In mills where corn-cobs are used to run the engines, the ashes furnish a considerable amount of potash.

The kernel of maize is so rich in starch that this grain forms our cheapest source of that important substance. Nearly all the starch used in this country, including "corn-stareh" and laundry stareh, is made from Indian corn. There are many large factories where the stareh is turned into a kind of sugar much used by confectioners. In the process of separating the starch there is also obtained a certain amount of oil. This has been used for illuminating purposes, for dressing wool, as a machine oil, and in the manufacture of soap. Maize oil is extracted also to some extent from the malted grain in distilleries which use Indian corn as a source of whiskey and alcohol. Nearly all the spirit now manufactured in the United States is made from maize.

Finally, it must be said that maize has been used also in various ormamental ways. Its attractive foliage and gracefnl appearance have led hortienlturists to plant it in gardens along with other ornamental grasses. They have, moreover, developed a special variety with striped leaves. Representations of the maize plant, as also of wheat, eotton, tohaceo, and oak appear upon United States dimes, while ears of Indian corn, together with sprays of the cotton plant 

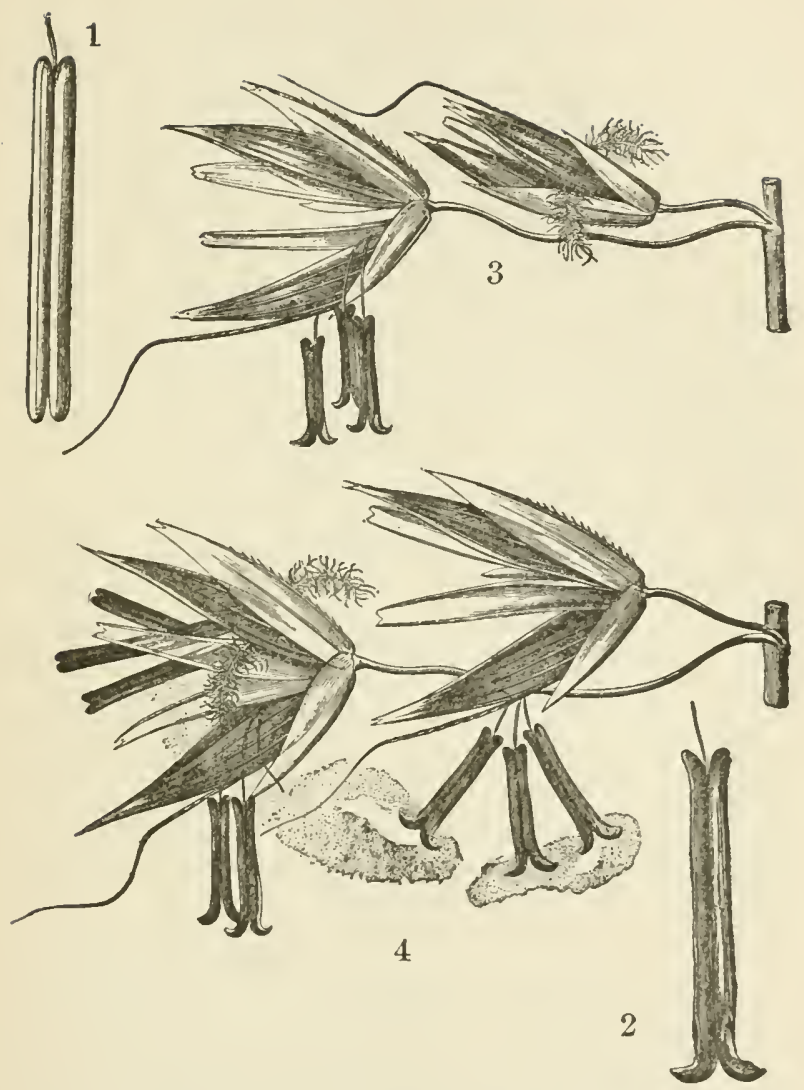

Frg. 31. Wild oat-grass. 1, a young anther. 2, a mature anther loolding its pollen exposed. 3 , two spikelets in still air; the left hand one with only stamens exposed, the other with only stigmas. 4, similar spikelets in a breeze, the left hand one having its pollen sacks empty before its stigmas are out, the otler with only stamens exposed and these shedding their pollen freely in the wind. All en. larged. (Kerner.) 
and heads of wheat, are ineluded in the design of our five-eent pieces of reeent issue. Maize and wheat appear also in the designis of the "Omaha" or TransMississippi postage stamps issued by the United States in 1898.

In further token of the importance of maize to our country it has been proposed to have this plant adopted for our national flower, so that it might stand as the symbol of our country as does the rose for England and the ehrysanthemum for Japan. Unfortunately for this idea, it is now well known that maize is not native within the territory of the United States. Moreover, we cannot class it as a flower in any popular sense of the word. For us to call what is neither a flower nor native onr national flower, would plainly be rilieulous. ${ }^{1}$ If, however, it should some day come to pass that the various eountries of North and Sonth and Central America shall join in one grand eonfederation, then surely no fitter emblem could be chosen to symbolize such a union of the nations of America than Indian corn, whose golden grain has proved to be the richest treasure of the West.

\section{Xit. A General View of Corn Plants.}

Let us now tie up our sheaf, and, taking a broad survey of the field throngh which we have passed, let us try to gain a just idea of the place of corn plants in the world. Our sturly of the cereal grains has led us in imagination back to a time long before

1 For a fuller disenssion of the merits of this and other candidates for Columbia's floral emblem see The National Flower IIovement, by the present writer, in the Transactions of the Massachusetts Ilorticultural Society for 1898. 


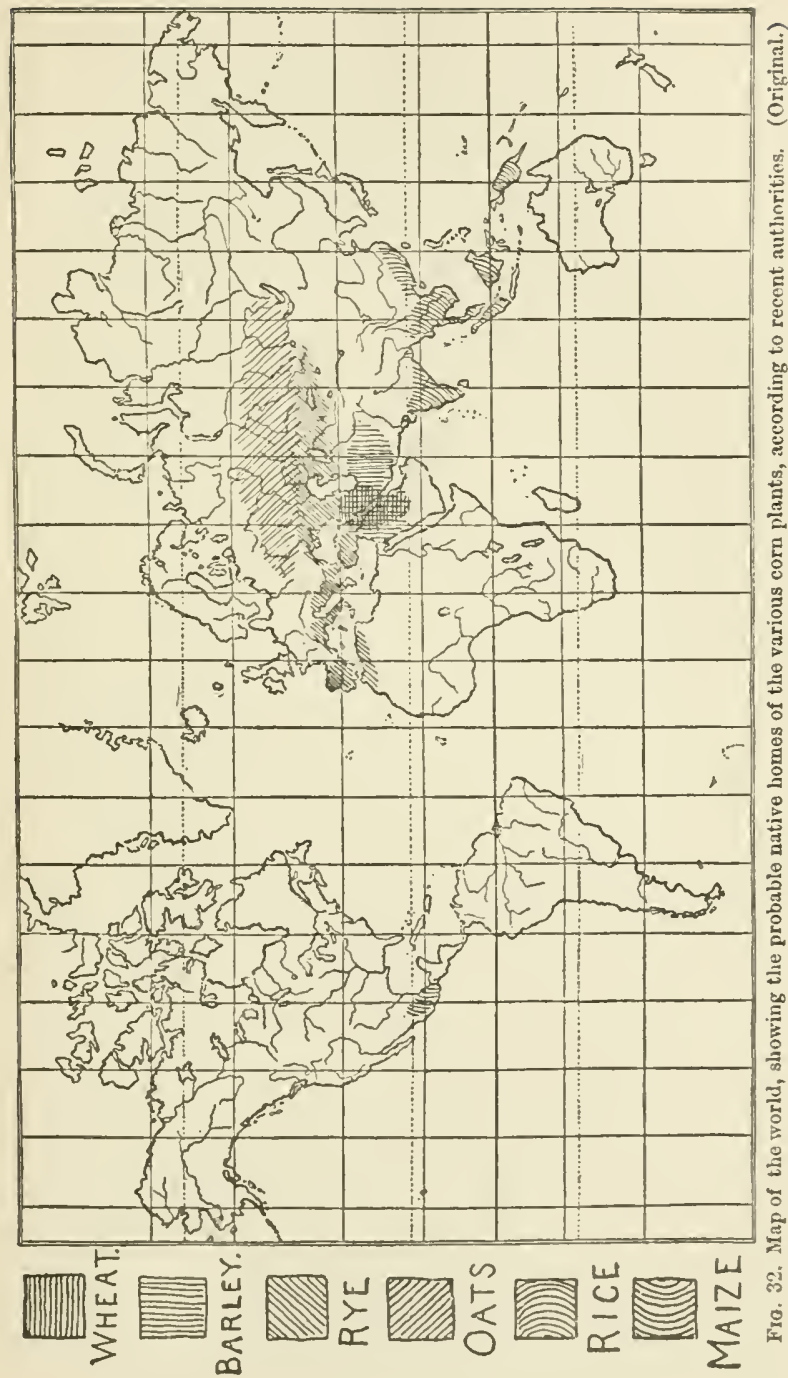


the dawn of eivilization, when our forefathers first gathered the grains of wild plants for their food. Since from seed-gathering, planting would easily follow, and from planting, agriculture ; and sinee agriculture would favor the founding of mighty nations and so make possible the highest achievements of mankind, we may see that no act of these early ancestors of ours was more full of promise for the lumman race than their choice of grains as a food.

This choice was first made, it would seem, by men who came to the rich valley of two rivers which lay at the centre of the ancient workl. Also in moist, hot lowlands of the far East, and on a fertile highland between the two great Western continents, a similar choice was made by other races of men perhaps ages after; while later still, it may be, ruder northern tribes in cooler and drier regions came to use the wild grains whieh grew near their hunting grounds.

However this ehoiee came about, we may say that in favored spots of North and West and East and Midland, man found awaiting him, among the many plants that sprang: luxuriantly from the soil, certain grasses which outdid all the rest in the abundance and quality of the food they offered him. These grasses were born to a life in the open fields where they could best obtain plenty of food-making sumsline; there they grew as if they had learned to outwit the wind and undo the harm of the pelting rain to which they were exposed; and when drought eame it lound them well prepared. Moreover, they marle the atmost use of every inch of ground, and formed vast brotherhoods which crowded ont less sturdy or less enterprising plants. But best of all were the advantages these plants seeured for their offspring. 
The seeds were so formed that the infant plant inherited the utmost vigor from its parents. Protection against various enemies was provided from the first. As soon as it was ripe, special arrangements were ready for its safe carriage by the wind to some farorable place of growth. Finally, against the time when the little traveler should begin life in a new home, an abundant supply of most nutritions food was packed within easy reach. This food was of sorts best fitted for transportation and keeping, and means were provided for readily converting it from the solid to the liquid form whenever needed. Everything was done to give the plantlet a good start in life.

It was but natural that plants which accomplished so much for themselves and provided so well for their offspring should be ehosen by man to supply his needs. Nor should we be surprised that they have proved to be the best of his providers.

He has repaid their bounty by his eare. As they have fed him, he has enriched the soil in which they grew; as they have helped him to travel, he has earried them to fresh fields in distant lands; as they have served him in war, he has fought against their enemies; as through their wealth man has multiplied, and great nations have peopled the earth, he has established these plants in ever inereasing numbers thronghout the world. Wild grasses and savages have thus through mutual help developed into cultivated cereals and civilized men.

During the long companionship of these two classes of beings, so different in their ways of life, and yet with needs so much alike, man has felt that he and they were somehow made to be of service one to the other. He has seen this doubly helpful dependence 
to be part of the wise plan of the Maker of all for the best good of each. As richer and richer harvests have yielded their reward for man's toil, he has felt an ever deepening thankfulness to the Giver of Life. Now, with new hope of the highest gifts, he asks his Father, "Give us this day our daily bread." 



\section{Che rituretion pregg}

Electrotyped and printed by 11 . O. Houghton \& Co.

Cambridge, Mass., U.S.A.

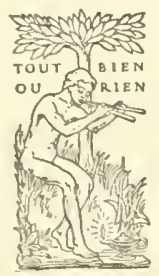



O/ University of British Columbia Library Books DATE DUE FE 201962 


\section{AGRICULTURE FORESTRY LIBRARY}

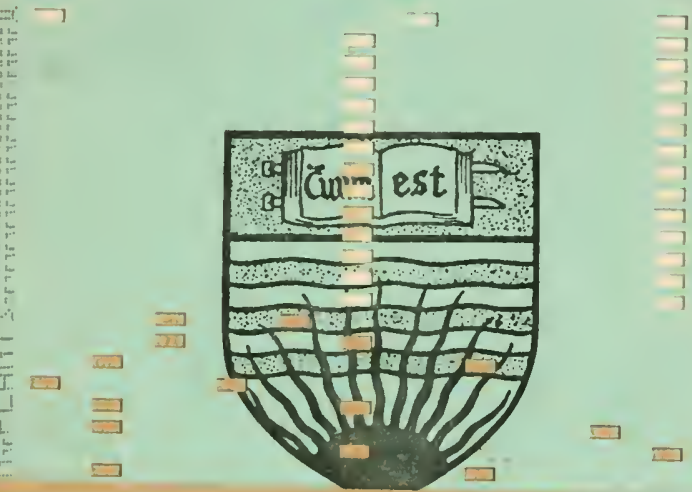

\section{FDRESTRY}

AERICULTURE

LIGRARY 
